\title{
HERKULES I GERION, KRÓLOWIE HISZPANII. MIT I JEGO RECEPCJA W IBERYJSKICH KRONIKACH DOBY ŚREDNIOWIECZA I NOWOŻYTNOŚCI
}

\begin{abstract}
Barbarzak Dawid, Herkules i Gerion, królowie Hiszpanii. Mit i jego recepcja w iberyjskich kronikach dobry średniowiecza i nowożytności (Hercules and Geryon, Kings of Spain. The Myth and Its Reception in Medieval and Modern Iberian Chronicles).

The ancient myth about Hercules' expedition to the island of Erythea, his combat with Geryon and setting the Pillars was adopted by the authors of Iberian chronicles from the Middle Ages and the Early Modern period. The paper responds to the question of how the myth was being changed by the authors and what their political or genealogical aim related with the historical period was. The analysis of ancient sources and the comparison with chosen Iberian chronicles proves that the character of Hercules was intentionally adapted for creating old dynastic genealogies, a model of good king or founding myths of Spanish cities (as Cádiz and A Coruña). For similar reasons, Spanish colonial expansion changed also the idea of the Pillars of Hercules which were not perceived as the boundary of the Mediterranean anymore but became a gate to the New World.
\end{abstract}

Keywords: founding myth; Hercules; Heracles; Melqart; Geryon; Spanish Chronicles; Pillars of Hercules; Gades; Cádiz; Gibraltar; A Coruña.

Cieśnina Gibraltarska, najbardziej wysunięty na zachód kraniec Morza Śródziemnego, od wieków stanowiła miejsce szczególne, w naturalny sposób wyznaczając granicę starożytnego świata. Przestrzeń znajdująca się dalej, oglądana jedynie podczas nielicznych wypraw kupców i badaczy (takich jak Pyteasz z Marsylii), najczęściej spowita była w liczne wyobrażenia mityczne. Starożytni obserwowali odwieczny spektakl, w którym słońce, uchodzące przecież za boga, rozświetlało czerwonym blaskiem wody Oceanu, schodząc do krainy, gdzie zwykli śmiertelnicy nie mieli dostępu ${ }^{1}$. Jeszcze Dante (Piekło 26.103-109) wkłada w usta Ulissesa opowieść o katastrofie statku, do której doszło właśnie u hiszpańskich wybrzeży:

${ }^{1}$ Za Słupami Heraklesa lokowano m.in. mityczną Atlantydę, o czym wspomina Platon (Tim. 24e-25a; Crit. 113-114) i Pliniusz Starszy (HN 6.36) oraz ogród Hesperyd, nimf zachodzącego słońca (Hes. Theog. 275). 


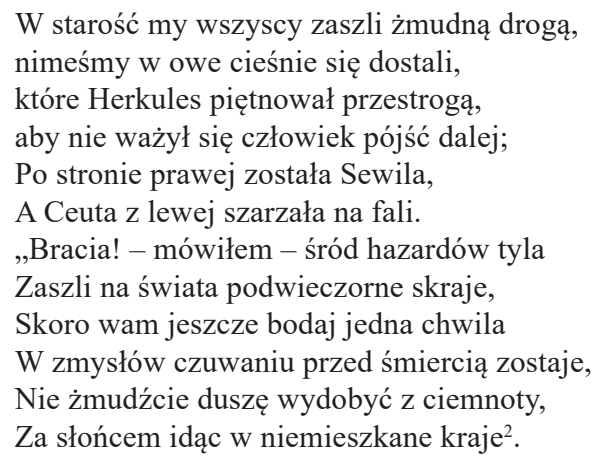

Słupy Heraklesa jawią się Dantemu jako brama do świata umarłych, ustanowiona przez Boga granica nie tylko geograficzna, ale i eschatologiczna. Fragment Boskiej komedii uzmysławia, jak trwały musiał być lęk starożytnych i średniowiecznych żeglarzy przed przekraczaniem Słupów Heraklesa. Mit o ich ustawieniu przez greckiego herosa podczas wyprawy po woły Geriona wiązano jeszcze w starożytności z ziemiami Iberii, a w późniejszych epokach szczególnie chętnie sięgali po tę historię średniowieczni i nowożytni autorzy kronik, tworzący na półwyspie. Z greckiego herosa uczynili oni postać legendarną, protoplastę iberyjskich dynastii i założyciela licznych miast czy budowli.

Temat obecności Herkulesa w iberyjskiej tradycji literackiej i materialnej doczekał się opracowań, głównie hiszpańsko- i anglojęzycznych. Część tych prac poświęcono Herkulesowi w dziedzinie archeologii ${ }^{3}$, w sztuce i architekturze ${ }^{4}$, część to opracowania ogólne ${ }^{5}$. Nie brakuje teoretycznych opracowań konkretnych kronik ${ }^{6}$. Spośród polskich publikacji poświęconych Herkulesowi warto wymienić monografię Herkules konkurent Chrystusa ${ }^{7}$, nie poruszającą jednakże zagadnień nas tutaj interesujących. Szczególnie cenną publikacją jest zbiór artykułów Prace Herkulesa - człowiek wobec wyzwań, prób i przeciwności, wydany jako materiały po konferencji zorganizowanej w 2011 roku przez Katedrę Komparatystyki Literackiej Wydziału Polonistyki UJ. Znajduje się w nim artykuł poświęcony Herkulesowi w hiszpańskiej kulturze ${ }^{8}$, traktujący jednak głównie o recepcji mitu w literaturze pięknej i sztukach plastycznych, mniej zaś w historiografii. Inny artykuł tej pracy zbiorowej mówi o Herkulesie w kontekście ideałów rycerskich i monarszych, co łączy się z tematem niniejszego rysu9 9

\footnotetext{
${ }^{2}$ Alighieri 1978: 143

${ }^{3}$ Corzo Sánchez 2005; Almagro Basch 1982.

${ }^{4}$ Vigo 2010; González García 1997.

${ }^{5}$ Oria Segura 1996; Plácido 1990; Blázquez Marínez 1984.

${ }^{6}$ Rico 1984.

${ }^{7}$ Szoka 2010.

${ }^{8}$ Hernández de la Fuente 2012.

${ }^{9}$ Pietrzak-Thébault 2012.
} 
Monografia Anny Boczkowskiej o programie ideowym epoki Jagiellonów sporo miejsca poświęca postaci Herkulesa, ale jedynie w kontekście polskim ${ }^{10}$, podobnie jak praca Jerzego Banacha Hercules Polonus ${ }^{11}$.

Celem niniejszego artykułu jest odpowiedź na pytanie, jak autorzy średniowiecznych i nowożytnych kronik, powstałych na Półwyspie Iberyjskim, czerpali z antycznej tradycji o wyprawie Heraklesa na kraniec świata, walce z Gerionem i ustawieniu słupów nazwanych imieniem herosa ${ }^{12}$. W toku rozważań przyjrzymy się ewolucji, jakiej podlegały antyczne, średniowieczne i nowożytne wyobrażenia o obecności Heraklesa na ziemiach należących dziś do Hiszpanii. Ponadto pragnę ukazać, w jaki sposób starożytni i nowożytni autorzy godzili mit o wyprawie greckiego herosa z obecnością sanktuarium Herkulesa w Gades (ob. Kadyks), biorącego swe początki od fenickiego kultu Melkarta. W badaniach tematu poddałem analizie wybrane źródła starożytne mówiące o obecności Herkulesa w fenickiej i rzymskiej Hiszpanii i jego kulcie (m.in. Hdt. 2.44, 4.152; Strab. 3.5.5; Apollod. Bibl. 2.5.10, Plin. HN 3.7.25; Mela $1.23,2.84,3.39$ ), fragmenty z kronikarzy średniowieczych (kronika Al-Rasiego i Jimeneza de Rady, Estoria de Espanna) i nowożytnych (Florián de Ocampo, Ambrosio de Morales, Juan de Mariana). Studium ukazuje, jak starożytny mit o herosie, który wyznaczył granicę poznanego świata wpłynął na mity założycielskie i genealogiczne średniowiecznej władzy monarszej oraz idei chrześcijańskiej rekonkwisty, by stać się w końcu imperialnym wyrazem hiszpańskiego kolonializmu zamorskiego w epoce Złotego Wieku. Brak podobnego, tak szczegółowego studium w dotychczasowych, polskich opracowaniach, skłonił mnie do przybliżenia tego tematu. Ponieważ praca bazuje na źródłach i własnej analizie, wierzę, że poza naświetleniem obcojęzycznych opracowań, niesie samodzielną wartość badawczą.

Artykuł składa się z dwóch części. Pierwsza stanowi przegląd źródeł antycznych traktujących o wyprawie Heraklesa i jego walce z Gerionem. Prezentuję w niej także różne opinie starożytnych autorów na kwestię Słupów Heraklesa. Wskazuję także, które z tych wersji okazać się miały szczególnie podatne na zapożyczenia w kontekście późniejszych dzieł kronikarskich. W drugiej części artykułu przytaczam wybrane fragmenty iberyjskich kronik przekazujących mit o Herkulesie i jego słupach. Wykazuję możliwą recepcję z antyku, wskazując jednocześnie, jak zmieniała się symboliczna wymowa Herkulesa w dziejach iberyjskiej historiografii. Na koniec uwaga o charakterze terminologicznym. Greckie imię bohatera, „Herakles”, stosuję wyłącznie w odniesieniu do autorów i źródeł greckich. Z kolei terminu „Herkules” używam, ilekroć mowa o epoce panowania rzymskiego i tekstach łacińskich oraz w kontekście średniowiecza

\footnotetext{
${ }^{10}$ Boczkowska 1993.

${ }^{11}$ Banach 1984.

${ }^{12}$ Blazquez 1980: 227.
} 
i nowożytności. „Hiszpańskimi” określam z kolei dzieła powstałe w Hiszpanii nie w geograficznym, ale politycznym kontekście, a więc po zjednoczeniu. Ponieważ omawiam też fragmenty z kronik średniowiecznych (także arabskich), czy - rzadszych co prawda - portugalskich i katalońskich, nazywam je zbiorczo „iberyjskimi”.

\section{WALKA Z GERIONEM I SŁUPY HERAKLESA W ŹRÓDŁACH ANTYCZNYCH}

Obecność Heraklesa na Półwyspie Iberyjskim łączymy najczęściej z jedną $\mathrm{z}$ jego prac, polegającą na uprowadzeniu wołów Geriona ${ }^{13}$. Z wyprawą wiąże się także podanie o pozostawieniu słynnych Słupów, które dla całej starożytności stały się symboliczną granicą znanego świata ${ }^{14}$. Wydarzenia te przyjmują u różnych autorów odmienne warianty, a ponadto nie zawsze są przez nich łączone. Zmianie ulega lokalizacja siedziby Geriona, właściwy cel wyprawy Heraklesa, a nawet tożsamość obydwu rywali. Również w odniesieniu do Słupów Heraklesa nie ma między autorami zgodności, czym właściwie były, jak powstały i gdzie dokładnie się znajdowały. Nasze rozważania zaczniemy więc od przeglądu źródeł dotyczących wyprawy do krainy Geriona, później zaś (o ile oczywiście tekst nie łączy obu wydarzeń), tych traktujących o Słupach Heraklesa. Najwcześniej o micie wspomina Hezjod w swej Teogonii (286-293):

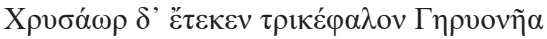

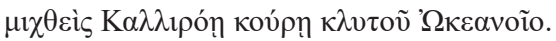

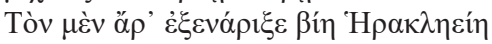

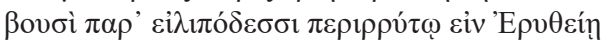

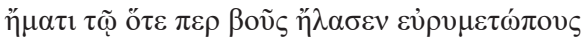

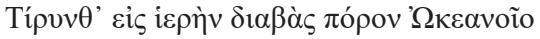

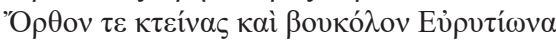

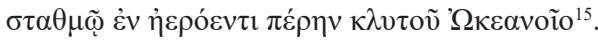
(Hes. Theog. 286-293).
\end{abstract}

Spłodził zaś Chrysaor Geryjona z trzema głowami, Gdy z Kalliroe się złączył, córką Okeanosa.

$\mathrm{Z}$ tego to ściągnął zbroję potężny mocarz Herakles

Blisko krów wolno kroczących w Erythii morzem oblanej

${ }^{13}$ Poza fragmentami wymienionymi w tekście, o micie tym traktują pomniejsze fragmenty, nieobjęte analizą w niniejszym rysie (Aesch. Ag. 870; Eur. Herc. 423ff.; Paus. 5.19.1; Hor. Carm. 2.14.7ff.; Verg. Aen. 6.289; Ov. Met. 9.184-185.; Hyg. Fab. 30, 151).

${ }^{14}$ Opowieść o herosie mającym porwać bydło trzygłowemu potworowi wydaje się pochodzić z tradycji indoeuropejskiej, bądź jest co najmniej wspólna dla tradycji greckiej oraz indoirańskiej, cf. Watkins 1995: 464-468; West 2007: 260-261.

${ }^{15}$ Hes. Theog. 286-293. 
W dniu tym, kiedy te krowy o łbach szerokich popędził

Do świętego Tirynsu, przekroczył cień Okeanu;

Zabił także Orthosa i Eurytiona wolarza

W ciemnych od mgły zagrodach za słynnym Okeanosem ${ }^{16}$.

(przeł. J. Łanowski)

Fragment ten, o charakterze ściśle genealogicznym, dość ogólnie umiejscawia całe zdarzenie na „morzem oblanej” wyspie Erythei leżącej gdzieś blisko Oceanu. Nazwę wyspy łączyć można z imieniem jednej z Hesperyd, czyli Wieczornic, o których poeta wspomina nieco wcześniej (274-276), a znaczenie

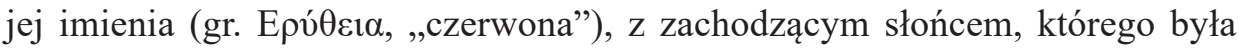
opiekunką ${ }^{17}$. Hezjod zaznacza, że celem wyprawy Heraklesa było uprowadzenie do Tirynsu „krów o łbach szerokich”. Autor nie wspomina jednak powodu, dla którego Herakles dopuszcza się kradzieży stad, ani o pracach nałożonych przez Eurysteusza. Heros wydaje się po prostu oczyszczać świeżo rodzący się świat od potworów. Czy jednak owa ,potworność” Geriona jest czymś uzasadniona? Z jednej strony Hezjod nazywa go trikefalón, „trzygłowym”, mającym, jak się wydaje, jeden wspólny korpus. Inne źródła, począwszy od Ajschylosa, będą już przedstawiać go z trzema odrębnymi korpusami i trzema parami kończyn. W tej postaci widnieje on także na ateńskich wazach $z$ VI w. p.n.e. ${ }^{18}$. Widzimy na nich antropomorficzną postać o trzech głowach zakutych w hełmy z charakterystyczną, wysoką kitą, w zbroi i nagolennikach, dzierżącą włócznie i tarcze (przyozdobione motywem węża, trypodu, orła czy głowy Meduzy, babki Geriona). W zestawieniu z odzianym w lwią skórę Heraklesem wygląda wręcz dostojniej, jakby reprezentował bogatą i silną cywilizację. Daleko mu do potworów znanych z pozostałych prac Heraklesa. Co ważniejsze jednak, w innym fragmencie

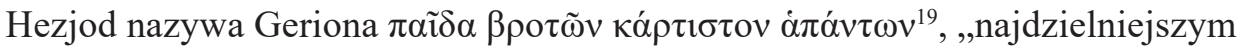
synem wśród śmiertelników", nadając mu cechy heroiczne. Był w końcu synem Chrysaora i boginki morskiej ${ }^{20}$. Te szlachetne cechy Geriona są istotne, gdyż inni autorzy antyczni będą go przedstawić jako króla i wodza, co w iberyj-

${ }^{16}$ Przekład z roku 1999 [http://katedra.uksw.edu.pl/biblioteka/hezjod_teogoinia.pdf], dostęp 15.09.2016.

${ }^{17}$ Apollodor czyni Erytheię jedną z czterech Hesperyd (za wydaniem: Apollod. Bibl. 2.511). Krańce zachodnie to także miejsce związane z narodzinami Meduzy czy Pegaza. Cf. Sanctis 2011: 58.

${ }^{18}$ Czarnofigurowa amfora attycka $550-540$ r. p.n.e. (Luwr, nr kat. Paris F53), czerwonofigurowy kyliks z 510-500 r. p.n.e. (Monachium, Staatliche Antikensammlungen, nr kat. 2620) czy lekyt attycki z końca VI w. p.n.e. (Archeological Museum of Delos). Te i inne przykłady można zobaczyć pod linkiem: [http://www.theoi.com/Gigante/GiganteGeryon.html], dostęp 01.03.2017.

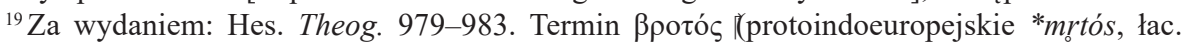
mortuus) podkreśla śmiertelność Geriona.

${ }^{20}$ Inaczej rzecz się ma u Stezychora w Gerioneidzie. Papirus PMGF S11 (vide Poetarum Melicorum ... 1991) przedstawia wątpliwości samego Geriona co do swej nieśmiertelności: jeśli jako syn Chrysaora jest nieśmiertelny i ma trafić na Olimp, gotów jest nawet oddać swe stada. Jeśli 
skich kronikach stanie się normą. Zauważmy także, że w pierwotnej wersji mitu Gerion jest jeden - co wydawać się może oczywiste - jednak w późniejszych źródłach będzie ich trzech. Obok głównych bohaterów pojawiają się również dwugłowy pies Orthos oraz pasterz Eurytion. Na wspomnianych wizerunkach ceramicznych malowano ich zwykle u stóp Heraklesa, rannych lub martwych. Naczynia przedstawiają herosa raz uzbrojonego w miecz, innym razem w maczugę czy łuk. Sposób, w jaki Herakles zgładził Geriona również będzie, jak zobaczymy, odmienny w zależności od tekstu.

Jedną z wersji lokalizujących spotkanie Heraklesa z Gerionem w Iberii (w krainie Tartessos), bogatszą niż fragment Hezjoda, jest Gerioneida sycylijskiego poety Stezychora z Chimery. Poemat zachował się jedynie we fragmentach papirusu ${ }^{21}$. Na opowieści tej bazuje najprawdopodobniej Pseudo-Apollodor w swej Bibliotece ${ }^{22}$. Walkę z Gerionem czyni on jedną z prac nałożonych Heraklesowi przez Eurysteusza dla odkupienia zbrodni dzieciobójstwa, które heros popełnił w szale zesłanym przez Herę (2.5.1). Praca ta, dziesiąta z kolei, miała być w założeniu ostatnią, jednak Eurysteusz dołożył dwie kolejne po tym, gdy Herakles uporał się z poprzednimi nim upłynęło dwanaście miesięcy planowanej służby. Przytoczmy historię w całości:

Jako dziesiątą pracę rozkazano mu sprowadzić stada Geriona z Erythei. Erytheia była wyspą przy oceanie; teraz nazywa się ona Gadeira. Wyspę tę zamieszkiwał Gerion, syn Chrysaora i Kalliroe, córki Oceanu. Miał ciało trzech mężczyzn zrośnięte razem, złączone w pasie, lecz rozdzielone na trzy od ud i boków. Posiadał czerwone stada, których stróżem był Eurytion, a dwugłowy Ortus, zrodzony z Tyfona i Echidny, był psem pasterskim. Podróżując przez Europę, by sprowadzić stada Geriona, pokonał wiele bestii i postawił stopę w Libii, a podążając do Tartessos wzniósł na znak swej podróży dwie naprzeciwległe kolumny na krańcach Europy i Libii. Lecz będąc spalonym Słońcem, napiął swój łuk przed bogiem [tj. Heliosem - przyp. DB]. Ten, w podziwie dla jego odwagi, darował mu złotą czarę, na której przepłynął ocean. Dotarłszy do Erythii, osiadł na górze Abas. Jednak pies, wytropiwszy go, ruszył na niego; lecz ten uderzył go maczugą, a kiedy na pomoc psu przyszedł Eurytion, zabił i jego. Lecz Menojtios, który pasł tam stada Hadesa, doniósł Gerionowi, co się stało. Ten spotkał Herkulesa nad rzeką Anthemus, prowadząc swoje stada na wypas. Wszczął z nim walkę, lecz został śmiertelnie postrzelony. A Herkules, wprowadził stada do czary i przeprawił się do Tartessos, gdzie zwrócił kocioł Heliosowi (przeł. D.B. ${ }^{23}$.

Herakles, otrzymawszy od Heliosa złoty kociołek (albo czarę, gr. $\delta \varepsilon ́ \pi \alpha \varsigma$ ), przeprawia się przez Ocean z Libii (czyli północnej Afryki) na Erythię. Tam zabija psa Orthosa i pasterza Eurytiona za pomocą maczugi (na lekycie z Monachium

natomiast jest śmiertelny i miałby doczekać starości z dala od nieśmiertelnych bogów, woli żyć. Cf. Sanctis 2011: 63.

${ }^{21}$ Są to zwłaszcza fragmenty: PMGF S16, S17, S21 i S87 Davies, cf. M. Lazzeri 2008: 43-44, $254-268$.

${ }^{22}$ Danielewicz 1984: LXXXVIII.

${ }^{23}$ Apollod. Bibl. 2.5.10. Przekład autora na podstawie: Apollodorus, The Library, przeł. J.G. Frazer, Loeb Classical Library Volumes 121 \& 122, London 1921. 
pies leży przebity strzałą), po czym staje do walki z Gerionem. Po licznych perypetiach podczas powrotu (jak próba kradzieży bydła w Italii) ${ }^{24}$, wyprawa kończy się doręczeniem wołów Eurysteuszowi, który składa je w ofierze dla Hery ${ }^{25}$. Autor dodaje także historię o ustawieniu słupów w Europie i Libii, o czym nie wspominał Hezjod. Obecność stad Hadesa strzeżonych przez Menojtiosa wskazuje, że miejsce to kojarzono z wejściem do świata umarłych. Jednak Apollodor jasno określa rzeczywistą geografię wyspy, wskazując, że znajduje się ona w krainie Tartessos, a jej współczesna nazwa to Gadejra. Jeszcze dokładniejszą geografię regionu znajdziemy u Pliniusza Starszego, opisującego dwie wyspy za Cieśniną Gibraltarską, z których jedna to Erytheia:

In ipso vero capite Baeticae ab ostio freti Gadis (...) habet oppidum civium Romanorum, qui appellantur Augustani Urbe Iulia Gaditana. Ab eo latere, quo Hispaniam spectat, passibus fere $\mathrm{C}$ altera insula est (...) in qua prius oppidum Gadium fuit, vocatur ab Ephoro et Philistide Erythea, Timaeo et Sileno Aphrodisias, ab indigenis Iunonis, majorem Timaeus Cotinusam aput Eos vocitatam ait; nostri Tarteson appellant. Poeni Gadir, ita Punica lingua saepem significante. Erythea dicta est, quoniam Tyri aborigines earum orti ab Erythro mari ferebantur. in hac Geryones habitasse a quibusdam existimatur, cuius armenta Hercules abduxerit. sunt qui aliam esse eam et contra Lusitaniam arbitrentur, eodemque nomine quandam ibi appellant ${ }^{26}$.

(Plin. NH 4.22.120)

Na końcu zaś samej Betyki, na 25.000 kroków od ujścia cieśniny morskiej, leży Gadyr (...) Ma miasto na prawie rzymskiem, które się zowie Urbs Julia Gadytana. Ze strony jej obróconej ku Hiszpanii, na sto prawie kroków leży druga wyspa (...) na niej było niegdyś miasto Gadyum. Eforus i Filistydes zwą ją Erytyą; Tymeusz i Sylenus, Afrodyzyą; mieszkańce wyspą Junony. Podług Tymeusza mieszkańce zowią większą Kotynussą; nasi nazywają ją Tartesson; Penowie Gadyr, co w punickim języku siedm oznacza ${ }^{27}$. Erytyą dla tego nazwaną została, iż pierwsi jej mieszkańce, Tyryjczykowie, przybyć tu mieli od Morza Erytrejskiego. Niektórzy mniemają, że na tej wyspie mieszkali Geryonowie, których bydło Herkules uprowadził, inni zaś twierdzą, że było to na innej wyspie, tego samego nazwiska, która w kierunku ku Luzytanii leżała.

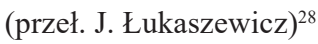

${ }^{24}$ Wergiliusz (Aen. 8.195-279, cf. Ov. Fast. 6.554.) dodał w tym miejscu historię o potworze Kakusie, który ukradł Herkulesowi część wołów. Na cześć pogromcy potwora ufundowano na rzymskim Forum Boarium ołtarz Ara Maxima wraz ze świątynią Herkulesa.

${ }^{25}$ Woły określa autor jako czerwone, podobnie jak sama wyspa. Inni autorzy będą później domniemywać, że dorodne stada w Epirze wzięły swój początek od przybyłych z Iberii wołów Heraklesa (cf. Ael. NA 12.11). Pauzaniasz wskazuje, że Herakles wracał do Grecji przez Sycylię (Paus. 4.36.3).

${ }^{26}$ Plin. $N H 4.22 .120$.

${ }^{27}$ To dawne tłumaczenie błędnie wyjaśnia etymologię fenickiej nazwy miasta Gadir. Występujące w oryginale „saepe” w tym przypadku należy przetłumaczyć jako „twierdza, mur obronny”. Podobnie definiuje się hebrajskie gādēr czy arabskie jadīr (Tregelles: 160). Taką też etymologię ma miasto Agadir w Maroku.

${ }^{28}$ Przekład z roku 1845. 
Tłumaczenie Łukaszewicza sugeruje, że Gerionów było kilku. Należy mieć jednak na uwadze, że imię Gerion występuje czasem w nominatiwie jako „Geriones", Pliniusz więc mógł mieć na myśli jednego Geriona. Wspominam o tym, gdyż niektóre wersje mitu, które później przytoczymy, zakładające istnienie trzech Gerionów, być może powstały na bazie tej rozbieżności w nazwie. Pliniusz wskazuje, że założycielami wyspy byli przybysze z Tyru. Odejdźmy więc na chwilę od mitologii i spójrzmy na Gadejrę i Tartessos z punktu widzenia zachowanych przekazów historycznych oraz tego, co mówi o tym miejscu współczesna nauka.

Dokładny opis geograficzny regionu oraz zróżnicowanie nomenklatury przedstawił Pliniusz Starszy w cytowanym fragmencie. Strabon zauważa, że niektórzy autorzy utożsamiali Erytheię, siedzibę Geriona, z samym miastem Gadeira, inni dopatrywali się Erythei w innej, pobliskiej wyspie. Dodaje, że mit o Gerionie zrodził się ze szczególnej obfitości traw, czyniących tamtejsze bydło wyjątkowo tłustym ${ }^{29}$. W starożytności w miejscu tym istniało kilka wysp (Ryc. 1), spośród których największą była Kotinousa ${ }^{30}$. Obecnie znajduje się na niej miasto Kadyks (hiszp. Cádiz). Autorzy przytoczonych fragmentów wymienili także Tartessos. Był to bogaty ośrodek handlowy, który już od przełomu III i II tysiąclecia utrzymywał kontakty handlowe ze wschodnim basenem Morza Śródziemnego. Zwłaszcza miasta fenickie sprowadzały stamtąd metale szlachetne ${ }^{31}$. Wyobrażeniom o bogactwach tej krainy, odpowiadać może etymologia imion ich mitycznych władców. Poza znanym nam Chrysaorem, oj-

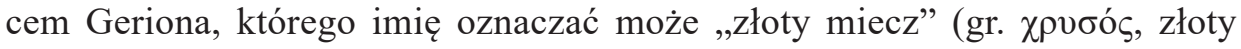
i öop, miecz) ${ }^{32}$, Herodot (1.163) wymienia jeszcze długowiecznego Argantoniosa, który nawiązał przyjazne stosunki z Fokijczykami. Jego imię przywodzi na myśl srebro. Kultura Tartessos, istniejąca na Półwyspie Iberyjskim jeszcze przed kolonizacją fenicką, a później silnie związana z wpływami wschodnimi, stanowi od dziesięcioleci przedmiot dyskusji naukowych, w których znaczącą rolę odgrywają odkrycia archeologiczne ${ }^{33}$. Kultura Tartessos podupadła w wy-

${ }^{29}$ Strab. 3.5.4-5; 3.2.11. Za wyspę uznaje Erytheję również Pomponiusz Mela (Mela 3.39).

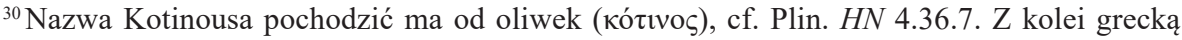
etymologię Gadejry wywodzi się od olbrzyma Gadejrosa (Eumelosa). Jak przytacza Platon (Crit. 114b), był on bliźniaczym bratem Atlasa i rządził archipelagiem Gadejry. Związki Atlasa i Herkulesa z krańcem zachodnim uwidaczniają się w micie o jabłkach Hesperyd, które heros zdobyć miał również w tym regionie świata.

${ }^{31}$ Tartessos bywa identyfikowane z biblijnym Tarszisz, które zaopatrywało Tyr w metale (Rdz 10.4-5; Ez 27.12; Jon 1.3). Herodot wspomina o Samijczykach, którzy pierwsi przybyli do tej krainy (Hdt. 4.152). Kontakty handlowe i przyjazne stosunki z królem Tartessos Argantoniosem rozwinęli Fokajczycy (Hdt 1.163). Mieszkańcy Tartessos rozwinęli własne pismo: według Strabona dysponowali księgami liczącymi 6 tys. lat (Strab. 3.1.6). Pauzaniasz zaznacza, że miasto to wzięło swą nazwę od rzeki Tartessos, później nazywaną Betis (stąd Betyka), cf. Paus. 6.19; Strab. 3.2.11.

${ }^{32} \mathrm{Za}$ wydaniem: Diod. Sic. 4.17.2.

${ }^{33}$ Ok. 925 r. p.n.e. pojawiają się w Tartessos pierwsze emporia fenickie. Wymiana handlowa z lokalną ludnością wpływa w późnej epoce brązu na ekonomiczny rozwój południowo-zachodniej 
niku ataków Luzytanów i została wchłonięta na skutek ekspansji Kartagińczyków, którzy ok. XI wieku p.n.e. założyli miasto Gadir, przez Greków nazywany Gadejrą. Stał się on najważniejszą kolonią fenicką na Płw. Iberyjskim, jednym z najstarszych miast tej części Europy ${ }^{34}$. Według podania, które przytacza Strabon, dopiero trzecia ekspedycja Tyryjczyków, wysłana przez wyrocznię w okolice Słupów Heraklesa, doprowadziła do założenia miasta oraz świątyni ${ }^{35}$. Bóstwem opiekuńczym kolonii był Melkart, którego w epoce hellenistycznej utożsamiono z Herkulesem ${ }^{36}$. Ważnym źródłem dla geografii i historii tego regionu jest Chorographia Pomponiusza Meli. Pochodził on z pobliskiego miasta Tingentery (2.96), którego mieszkańcy byli potomkami Fenicjan mieszkających w afrykańskich koloniach, przesiedlonymi najprawdopodobniej na drugą stronę cieśniny. Temat Słupów Heraklesa i fenickiej przeszłości okolic znał więc Mela osobiście ${ }^{37}$. Opisuje on położenie wyspy Gades i znajdujące się tam sanktuarium Herkulesa:

His oris quas angulo Baeticae adhuc usque perstrinximus multae ignobiles insulae et sine nominibus etiam adiacent, sed earum quas praeterire non libeat Gades fretum adtingit, eaque angusto spatio et veluti flumine a continenti abscissa qua terris propior est paene rectam ripam agit, qua oceanum spectat duobus promunturiis evecta in altum, medium litus abducit, et fert in altero cornu eiusdem nominis urbem opulentam et fert in altero cornu eiusdem nominis urbem opulentam, in altero templum Aegyptii Herculis, conditoribus religione vetustate opibus inlustre. Tyrii constituere; cur sanctum sit, ossa eius ibi sita efficiunt; annorum quis manet ab Iliaca tempestate principia sunt; opes tempus aluit.

(Mela 3.6.46)

Na tych wybrzeżach, które od krańca Betyki aż dotąd opisaliśmy, leży wiele niepoznanych wysp, przy których leżą także niemające nazw. Ale z tych, których nie wypada pominąc milczeniem, jest Gades, leżąca przy cieśninie. Oddziela ją od kontynentu wąska przestrzeń, jakby rzeka. Od strony lądu tworzy prawie prostą linię, a w stronę Oceanu kieruje dwa przylądki, a pośrodku brzeg jest cofnięty. W jednym narożniku leży bogate miasto o tej samej nazwie, na drugim wznosi się świątynia egipskiego Herkulesa, słynna dzięki założycielom i ze względu na swą starodawność, kult oraz bogactwo. Świątynię założyli Tyryjczycy, a miejsce to jest

części półwyspu. Na brzegach Gwadalkiwiru rozwija się rolnictwo i hodowla bydła, co wiąże się z mitem o stadach Geriona (Strab. 3.5.4), cf. Torres Ortiz 2002: 101-103; González Wegner 2014: 20 (więcej o Tartessos w pracach wymienionych autorów).

${ }^{34}$ Radziszewski 2005: 163. Więcej o historii i mitach związanych z tym fenickim miastem przedstawia J.A. Fierro Cubiella, Gadir la historia de un mito, Cádiz 1995.

${ }^{35} \mathrm{Za}$ wydaniem: Strab. 3.5.5. Autor przytacza tę legendę za Posejdoniosem z Rodos.

${ }^{36}$ Lomas Salmonte 2005: 113. Miejsce to uchodziło za jeden z tzw. świętych przylądków (gr.

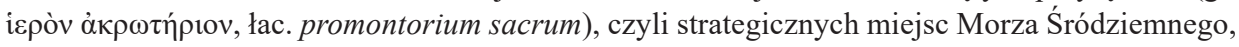
gdzie zwykle budowano świątynie dla bóstw morskich. Strabon nie wspomina o świątyni na przylądku, ale o świętych kamieniach. W miejscu tym składano libacje i nie można było zostawać tam na noc, przez wzgląd na obecność bogów (Strab 3.1.4-5). Podobnym przylądkiem był np. Sunion w Grecji ze świątynią Posejdona.

${ }^{37}$ Szarypkin 2011: 13-14. 
święte, gdyż pochowane są tutaj jego kości [tj. Herkulesa - przyp. aut]. Początki jej lat przypadają na wojnę trojańską. Czas jeszcze dodał jej zamożności.

(przeł. D.B.)

Zauważmy, że w mieście Gades miały znajdować się kości Herkulesa. Sugerować to może istnienie już w starożytności wierzenia upatrującego miejsca śmierci Herkulesa w Hiszpanii. Przekonanie to zachowa się do czasów średniowiecznych i będzie powtarzane, jak zobaczymy, we wszystkich niemal kronikach iberyjskich. Ciekawy mit łączący postać Herkulesa z wynalezieniem tyryjskiej purpury odnaleźć można u Grzegorza z Nazjansu (Oratio 4.108) oraz Kasjodora (Variae 1.2). Podają oni historię o tym, że gdy pewnego razu Herkules i nimfa Tyrus spacerowali po plaży, nagle pies Herkulesa znalazł ślimaka z gatunku $m u$ rex brandaris i ufarbował sobie pysk jego pigmentem. Nimfa zagroziła, że nie prędzej zostanie kochanką herosa, póki ten nie ofiaruje jej szaty w podobnym kolorze. Herkules miał nazbierać ślimaków i stworzyć tym samym purpurę tyryjską. Warto dodać, że w płytkich wodach okalających Gadir, feniccy koloniści mieli tych ślimaków pod dostatkiem, a miejsce to było istotnym producentem tyryjskiej purpury ${ }^{38}$.

Opisane przez Pomponiusza Melę sanktuarium Herkulesa powstało na bazie świątyni Melkarta. Dziś jego ruiny kryje niewielka wysepka Sancti Petri, która oddzieliła się od centralnej wyspy (Ryc. 1) ${ }^{39}$. W przeszłości była to jedna z najważniejszych świątyń zachodniego świata, najpierw dla Fenicjan, później także dla Rzymian. To tutaj Hannibal miał złożyć swe wota przed drugą wojną punic$\mathrm{kąa}^{40}$. Wiele lat później, gdy Betyka była już rzymską prowincją, do sanktuarium przybyć miał Juliusz Cezar. Zapłakał ponoć przy posągu Aleksandra Wielkiego, zdając sobie sprawę, jak mało dotąd osiągnął w porównaniu z Macedończykiem $^{41}$. W muzeum miejskim w Kadyksie zobaczyć można fenickie figurki z brązu przedstawiające Melkarta (odnalezione na wyspie Sancti Petri), a także późniejszą figurkę rzymską z inicjałem „H.G”, odczytywanym jako „Hercules

${ }^{38}$ Charakterystyczne muszle tego ślimaka można odnaleźć na brązowych monetach tyryjskich z okresu Heliogabala (BMC 393, 396, 407, 411 i. in.), cf. [http://www.wildwinds.com/coins/ric/ elagabalus/t.html], dostęp 02.03.2018. Mieszkańców położonej przy Kadyksie wyspy San Fernando, a także samą wyspę, do dziś nazywa się terminem cañailla, będącym określeniem wspomnianego ślimaka. Stanowi on popularne danie w Andaluzji.

${ }^{39} \mathrm{Na}$ zachodnim krańcu centralnej wyspy, mieściła się świątynia Baal-Hamona, którą Strabon identyfikuje z Kronosem (Strab 3.5.3). Na położonej obok wyspie Erytheja (Ryc. 1) istniało sanktuarium Asztarte. Melkart, jako bóstwo solarne, co wieczór wyruszał na daleki Zachód, by poślubić boginię, cf. Tyloch 1988: 332. Z mitem tym mogła wiązać się lokalizacja sanktuarium Asztarte na zachodzie, Melkarta zaś nieco na wschodzie. Według Józefa Flawiusza, podobna konfiguracja świątyń znajdowała się w Tyrze, gdzie król Hiram w X w. p.n.e. zburzył dawne świątynie, stawiając jedną dla Heraklesa, drugą dla Asztarte (Joseph. $A J$ 8.5.3). Ponieważ Asztarte była utożsamiana z Afrodytą, być może dlatego Pliniusz ( $N H 4.120)$ wspomina, że wyspę nazywano Afrodyzją.

${ }^{40} \mathrm{Za}$ wydaniem: Liv. 21.21.9.

${ }^{41} \mathrm{Za}$ wydaniem: Suet. Iul. 7.1, cf. Graves 1974: 177. 


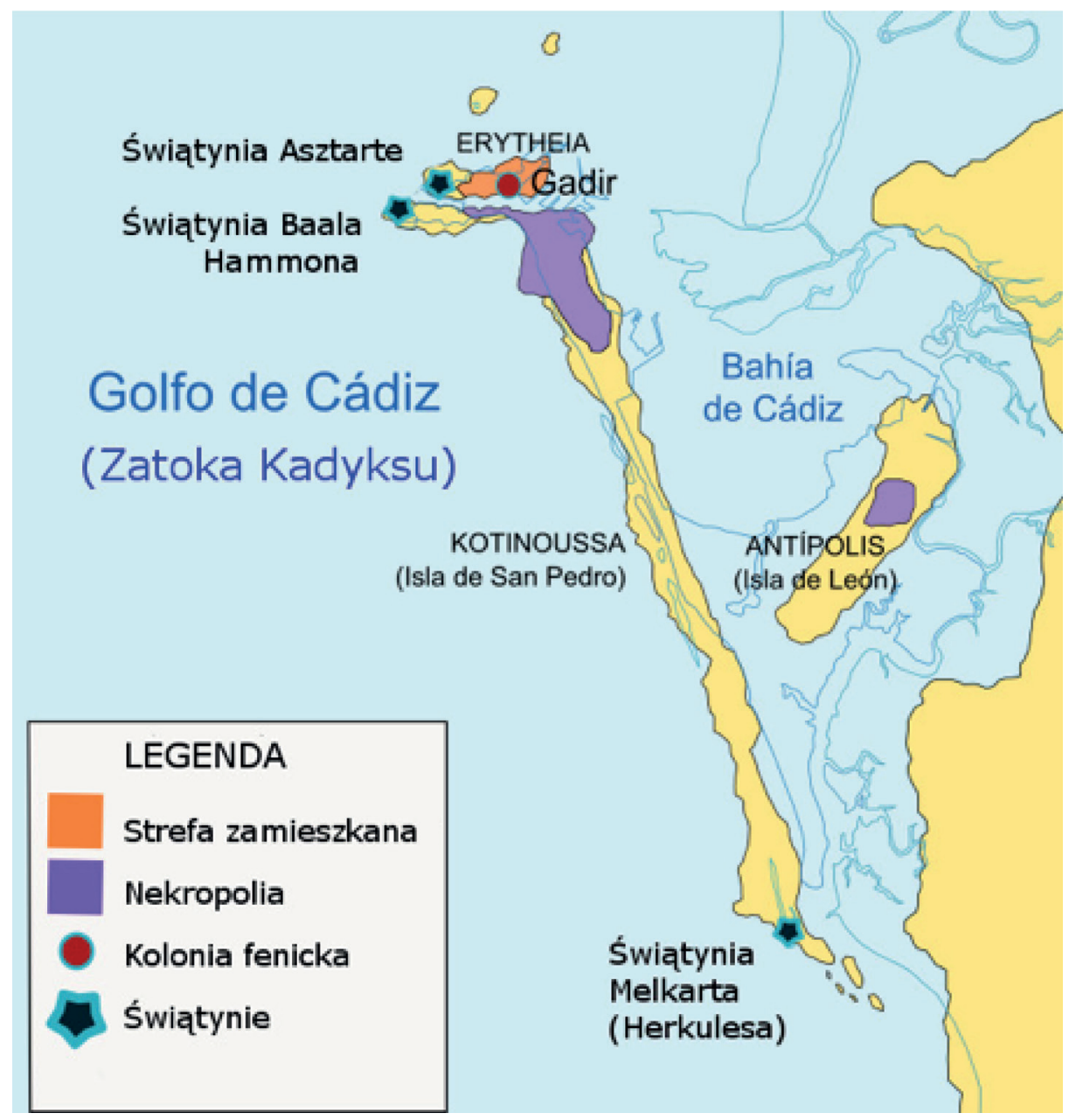

Ryc. 1. Mapa kolonii Gadir w czasach fenickich z zaznaczoną świątynią HerkulesaMelkarta.

Źródło: [https://es.wikipedia.org/wiki/Historia_de_Cádiz\#/media/File:Gadeiras314.svg] (dostęp 12.03.2018)

Gaditanus” czyli „Herkules z miasta Gades”"2. Świątynia cieszyła się rozkwitem w czasach Trajana, w IV wieku zaczęła podupadać, by w XII stuleciu ulec zniszczeniu przez szukających skarbów Almorawidów.

Powiedzieliśmy, że w świecie grecko-rzymskim czczone przez Fenicjan bóstwo opiekuńcze utożsamiono z Herkulesem. Jednak wielu autorów zdało sobie sprawę, że bóg przybyszów z pradawnego Tyru nie może być tym samym, co stosunkowo młody heros grecki. Pomponiusz Mela w przytoczonym fragmencie

\footnotetext{
${ }^{42}$ Corzo Sánchez 2005: 91-122.
} 
mówi o świątyni „egipskiego Herkulesa”. Jeszcze w starożytności zaczęto więc rozróżniać dwóch, a nawet kilku Heraklesów. Rozważenie tej kontrowersji w tym miejscu jest dla nas istotne, gdyż również w iberyjskich kronikach znajdziemy głosy o kilku Herkulesach. Flawiusz Arrian w swej Anabazie, powołując się na historyka Hekatajosa z Miletu (ok. 550-480 p.n.e.), twierdzi, że feniccy mieszkańcy Tyru czcili swojego Heraklesa zanim jeszcze Kadmos wyruszył do Teb. Ponieważ grecki Herakles żyć miał dopiero w czasach Edypa, musiał być młodszy od swego fenickiego ,imiennika”. Który z nich wyruszył po woły Geriona? Arrian czyni następujące rozróżnienie:

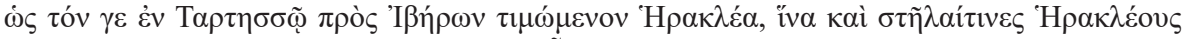

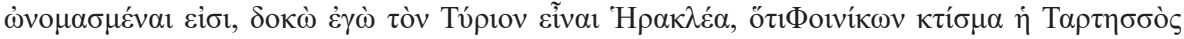

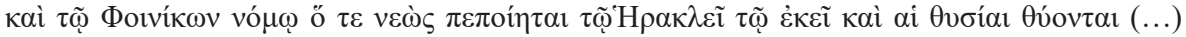

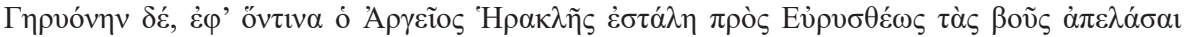

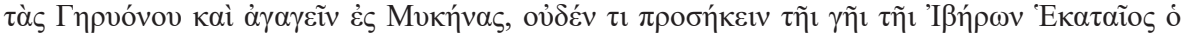

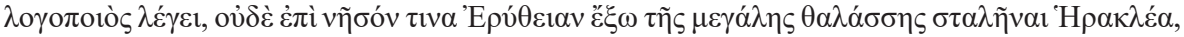

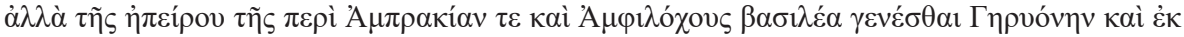

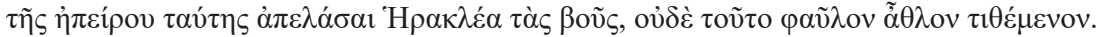

(Arr. Anab. 2.16.4-5.)

(...) myślę, że Herakles czczony w Tartessos przez Iberów, gdzie znajdują się słupy zwane od Heraklesa, to tyryjski Herakles; gdyż Tartessos było kolonią Fenicjan i zbudowano tam Heraklesowi świątynię (...) Historyk Hekatajos mówi, że Gerion, przeciw któremu Eurysteusz wysłał argiwskiego Heraklesa, by ten uprowadził jego woły i sprowadził je do Myken, nie miał nic wspólnego z krajem Iberów; ani też Heraklesa nie wysłano na żadną wyspę zwaną Erytheją, znajdującą się za Wielkim Morzem. Gerion był raczej królem kraju leżącego przy Ambrakii i Amfilochii, któremu Herakles uwiódł woły z Epiru i nie było to trudne zadanie. (przeł. D.B.)

Autor dodaje, że i w jego czasach wspomniane greckie krainy obfitują w piękne gatunki wołów. Wątpi, by Eurysteusz mógł znać imię króla Iberów, których nazywa „najodleglejszym narodem w Europie” oraz gatunki wypasanego tam bydła. Jeśli więc wierzyć Arrianowi, związany z Iberią Herakles Tyryjski (czy Egipski, jak nazywa go Mela), nie ma nic wspólnego z Gerionem. Arrian wyróżnia zresztą jeszcze trzeciego Heraklesa, czczonego w Egipcie, powołując się tym razem na Herodota. Ten, jak czytamy w Dziejach, już wcześniej podjął się zbadania kontrowersji i specjalnie udał się w tym celu do Tyru:

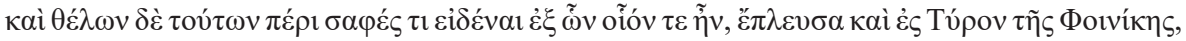

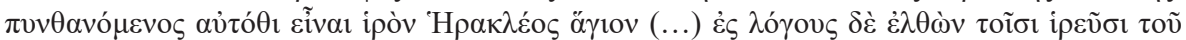

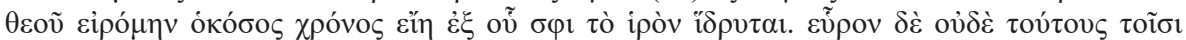

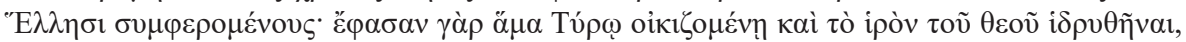

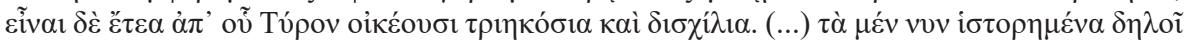

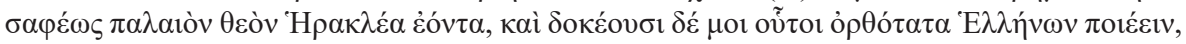

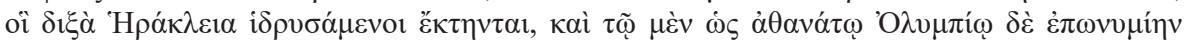

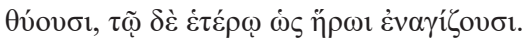

(Hdt. 2.44.1-5.) 
Chcąc o tym uzyskać jakąś pewną wiadomość od ludzi, którzy mogli mi jej udzielić, popłynąłem nawet do Tyru w Fenicji, bo słyszałem, że tam znajduje się chram poświęcony Heraklesowi (...) Wdałem się w rozmowę z kapłanami boga i zapytałem ich, ile minęło czasu od chwili wzniesienia tej świątyni. Ale przekonałem się, że i ich odpowiedź nie zgadza się z tym, co mówią Hellenowie; mówili bowiem, że tę świątynię wzniesiono bogu wraz z założeniem Tyru, a Tyros zaludnione jest już od dwóch tysięcy trzystu lat (...) Co więc zbadałem, to jasno dowodzi, że Herakles jest dawnym bogiem. I zdaje mi się, że najsłuszniej postępują ci Hellenowie, którzy wybudowali u siebie dwie świątynie Heraklesa; mianowicie jednemu, jako nieśmiertelnemu bogu z przydomkiem Olimpijskiego, składają ofiary, drugiego czczą jako herosa ${ }^{43}$.

(przeł. S. Hammer)

Opinia Herodota zapoczątkowała myśl, według której istniał nie tylko jeden Herakles, ale kilku, z których starsi mieli być czczeni w Egipcie i Fenicji ${ }^{44}$. Myśl tę powtarzać będą również inni autorzy. Diodor Sycylijski wyróżni już trzech Herkulesów (egipskiego, kreteńskiego i greckiego) ${ }^{45}$, a Cyceron aż sześciu ${ }^{46}$. Jednakże Herodot, co dla nas istotne, mimo rozróżnienia Heraklesów, wcale nie odmawia Gerionowi siedziby na krańcach zachodnich. W innym miejscu przytacza bowiem historie zasłyszane od Greków nad Morzem Czarnym:

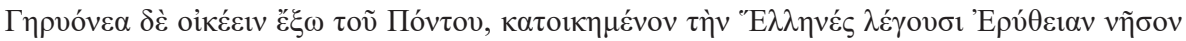

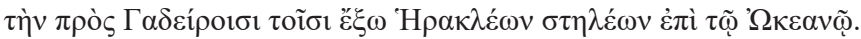

(Hdt. 4.8.1-2).

Geriones zaś mieszkał poza Morzem i miał siedzibę na wyspie, którą Hellenowie nazywają Eryteją, w pobliżu miasta Gadejra, poza Słupami Heraklesa na Oceanie (przeł. S. Hammer) ${ }^{47}$.

\footnotetext{
${ }^{43}$ Przekład z roku 2005 (s. 117-118).
}

${ }^{44}$ Fenickiego Melkarta utożsamiano w greckiej mitologii z Melikertesem, wnukiem Kadmosa z Tyru. Było to bóstwo morskie, „stróż okrętów” (Eur. IT 270, tu Melikertes pod imieniem Pelajmon), cf. Ov. Met. 4.416ff. Ponadto Heraklesa uznawano nieraz za syna Zeusa i Asterii (Asztarte?), która miała się rzucić w morze jako przepiórka, uciekając przed zalotami Zeusa (Hyg. Fab. 53). Mit ten łączy się z innym podaniem, według którego Herakles, zabity w Egipcie przez Tyfona, zbudził się do życia dzięki woni pieczonej przez Jolaosa przepiórki (Ath. Deipn. 9.392). Atenajos, powołując się w tym fragmencie na Eudoksosa z Knidos, podaje, że właśnie dlatego Fenicjanie składają Heraklesowi przepiórki w ofierze. Trudno ustalić dokładne relacje między Heraklesem i Melkartem, podobnie jak między innymi wschodnimi bohaterami, jak żydowski Samson, cylicki Sandas czy mezopotamski Gilgamesz, cf. Morford, Lenardon 1991: 480.

${ }^{45}$ Diod. 3.74.

${ }^{46}$ Cic. Nat. D. 3.42. Cyceron wśród sześciu Herkulesów wymienia również Tyryjskiego, najbardziej czczonego przez Fenicjan, syna Jowisza i tytanidy Asterii (siostry Leto). Cf. H.C.R. Vella 1986. Sześciu Herkulesów wyróżnia także historyk Lucjusz Ampeliusz. W IX rozdziale Liber memoralis czytamy: „Hercules sex: primus Iovis [et] Aetherii filius; secundus Nili filius quem principem colunt Aegypti; tertium conditorem loci sui Hellenes dicunt; quartus Croni filius et Carteres quem Carthaginenses colunt, unde Carthago dicta est; quintus Ioab filius qui cum rege Medorum pugnavit; sextus Iovis filius ex Alcemena qui Atlanta domuit".

${ }^{47}$ Przekład z roku 2005 (s. 231). 
Można więc domniemywać, że Herodot wierzył w daleką wyprawę Heraklesa, skoro siedzibę Geriona lokalizuje w miejscu, gdzie wznoszą się ustawione przez niego Słupy. Iberyjskie kroniki również wyszczególniać będą czasem kilku Herkulesów, raz w starszym, innym razem w młodszym widząc protoplastę dynastii, ale oczywiście nie wyprą z hiszpańskich ziem Geriona i historii o jego spotkaniu z Herkulesem. Wydaje się jednak, że najbardziej istotną dla kronik iberyjskich wersją opowieści jest ta przedstawiona przez Diodora Sycylijskiego.

Zauważmy, że Herakles Hezjoda i Apollodora to heros walczący w pojedynkę, skupiony na sprowadzeniu wołów. U Diodora Sycylijskiego oraz w późniejszych kronikach iberyjskich ta optyka wyraźnie się zmieni: kwestia wołów odejdzie w cień na rzecz podkreślenia osoby Heraklesa-króla i wodza niosącego cywilizację. Herakles już przed wyprawą zbiera flotę i wojsko, by stawić czoła nie trzygłowemu Gerionowi, ale trzem synom Chrysaora i armiom, które ci zebrali wśród iberyjskich plemion:

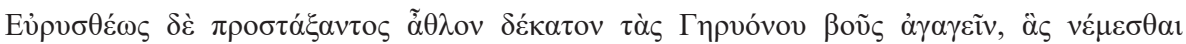

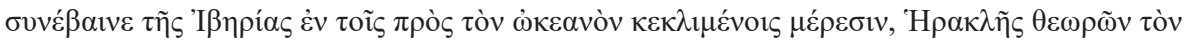

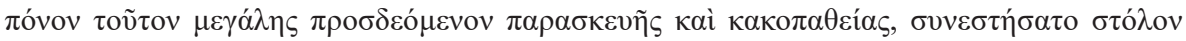

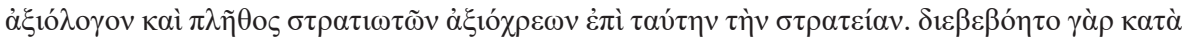

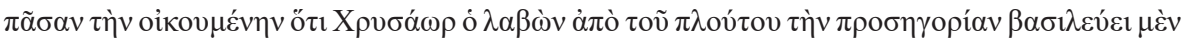

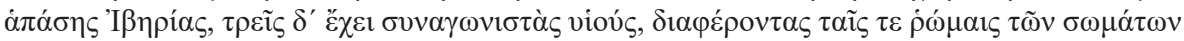

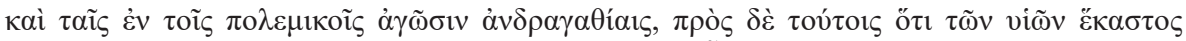

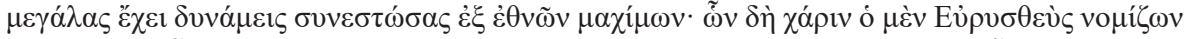

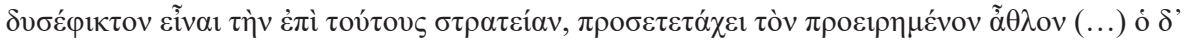

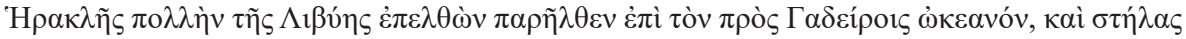

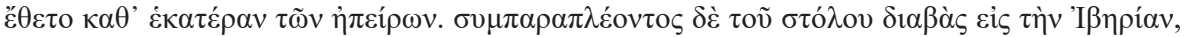

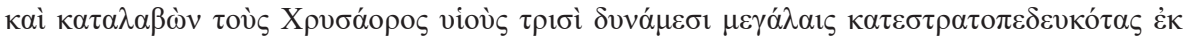

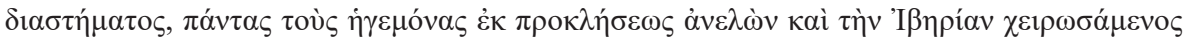

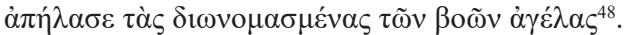

(Diod. Sic. 4.17-18.)

Eurysteusz zadał mu wtedy jako dziesiątą pracę sprowadzić stada Geriona, wypasane w części Iberii leżącej nad Oceanem. A Herakles, zdając sobie sprawę z zadania, wezwał do wielkich przygotowań: zebrał znaczące uzbrojenie oraz thum żołnierzy, odpowiednie dla takiej wyprawy. Głośno było bowiem na całym zamieszkałym świecie, że Chrysaor [Złoty miecz - przyp. D.B.], który otrzymał ten przydomek ze względu na swoje bogactwa, był królem nad całą Iberią i miał trzech synów, walczących u jego boku, którzy wyróżniali się siłą cielesną i męstwem, którego dowiedli w licznych potyczkach wojennych; wiadomo było, że każdy z tych synów miał do dyspozycji wielkie siły wojska, zebranego wśród wojowniczych plemion. To właśnie z powodu tych podań, Eurysteusz, myśląc, że wyprawa przeciw tym ludziom będzie zbyt trudna do spełnienia, przypisał Heraklesowi opisaną tu pracę [...] Gdy Herakles odwiedził znaczną część Libii, przybył nad ocean, blisko Gadeiry, gdzie ustawił kolumny na obu kontynentach. Jego flota towarzyszyła mu przez całe wybrzeże i dzięki niej przedostał się do Iberii. A znajdując tam synów Chrysaora, obozujących w pewnej odległości od siebie z trze-

${ }^{48}$ Diodor ma tutaj na myśli Heraklesa egipskiego, który ze swoim wojskiem podbił większość świata i postawił kolumny, nie zaś syna Alkmeny, narodzonego krótko przed wojną trojańską. 
ma wielkimi armiami, wyzwał każdego z wodzów na pojedynek i zgładził każdego z nich. A podbiwszy później Iberię, wywiózł słynne stada.

(przeł. D.B.)

Chrysaora przedstawia Diodor jako bogatego króla, władającego nad całą Iberią. Herakles zmierza na zachód przez Libię, gdzie w zapasach gładzi giganta Anteusza $^{49}$, a w Egipcie okrutnego króla Buzyrysa. Heros w swej drodze cywilizuje Libię, kraj dotąd pustynny, pełen przestępców i dzikich zwierząt. Także w Iberii, po pokonaniu synów Chrysaora, Herakles odnawia kraj, zostawiając go pod władzą miejscowego nowego króla, który ustanowi kult Heraklesa-wybawiciela:

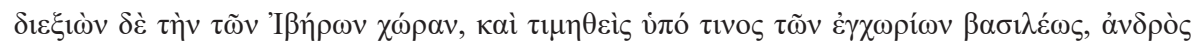

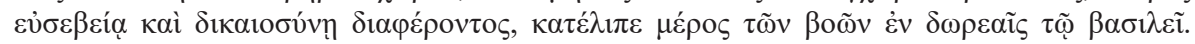

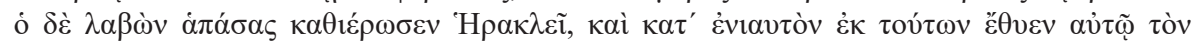

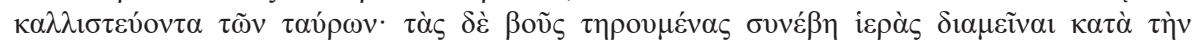

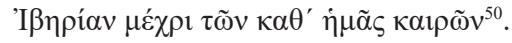

(Diod 4.18.3.)

Później przemierzył kraj Iberów, a skoro otrzymał wiele honorów z rąk pewnego króla lokalnej ludności, człowieka wyróżniającego się pobożnością i sprawiedliwością, zostawił królowi część bydła w prezencie. Król przyjął je, ale całe poświęcił Heraklesowi i zapoczątkował zwyczaj składania w ofierze dla Heraklesa najpiękniejszego byka ze stada; i stało się tak, że wciąż w Iberii hoduje się bydło i nadal poświęca Heraklesowi aż do naszych czasów.

(przeł. D.B.)

Zauważmy, że w relacji Diodora nie pada imię „Gerion”, a mowa jest o „synach" Chrysaora. To stąd najpewniej bierze się późniejsza wersja powtarzana w iberyjskich kronikach o trzech Gerionach i ich armiach. Herakles Diodora jawi się więc już nie jako mitologiczny heros, walczący sam na sam, ale jako wódz, który wprowadza porządek i prawo, niesie cywilizację, zaczyna uprawiać ziemie dotąd leżące odłogiem. Ten właśnie wizerunek Heraklesa przejmą kronikarze średniowieczni i nowożytni.

Dodatkowym argumentem świadczącym o obecności herosa w Iberii są Słu-

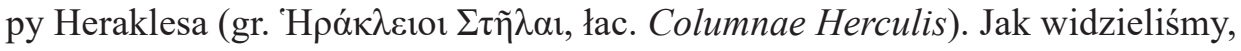
liczni autorzy nazywali w ten sposób czysto geograficznie Cieśninę Gibraltarską (istniało także określenie Fretum Herculaneum). Strabon przytacza sprzeczne opinie różnych autorów odnośnie tego, czym właściwie są i gdzie dokładnie znajdują się owe Słupy Heraklesa. Według niektórych są to przylądki po obu stronach cieśniny, które tworzą jakoby usta czy wrota. Tak o miejscu tym wyrazić miał się Pindar, który po raz pierwszy nazwał słupy $\pi \dot{\lambda} \lambda \alpha_{\varsigma} \Gamma \alpha \delta \varepsilon \imath \rho i ́ \delta \alpha \varsigma$,

${ }^{49}$ Zwykle mówi się o tym pojedynku w kontekście wyprawy do Ogrodu Hesperyd (cf. Serv. Verg. A. 8.300). Zauważmy jednak, że podobnie jak siedzibę Geriona, lokalizowano go na krańcach zachodnich, a prace te podaje się jako następujące po sobie (dziesiąta i jedenasta).

${ }^{50}$ Diod 4.18.3. 
„wrotami Gadeiry" ${ }^{51}$. Jeszcze inni wskazują dokładniej, że są to wzgórza Calpe (po stronie europejskiej) i Abyla (po stronie Libii) albo wyspy leżące w ich pobliżu, z których jedna to Wyspa Hery (a więc chyba Erytheja, jak wskazały przytoczone fragmenty $)^{52}$. Również Pomponiusz Mela rozumie przez Słupy Heraklesa przylądki, który niegdyś tworzyły jeden ląd. Przy opisie Mauretanii pisze on:

Deinde est mons praealtus, ei quem ex adverso Hispania adtollit obiectus: hunc Abilam, illum Calpen vocant, Columnas Herculis utrumque. Addit fama nominis fabulam, Herculem ipsum iunctos olim perpetuo iugo diremisse colles, atque ita exclusum antea mole montium oceanum ad quae nunc inundat admissum.

(Mela 1.27.)

Dalej leży bardzo wysoka góra, stojąca naprzeciw drugiej wznoszącej się w Hiszpanii, na przeciwległym brzegu. Po tej stronie górę nazywają Abila, a tą na drugim brzegu Calpe; razem nazywają je Słupami Herkulesa. Ustna tradycja tak opowiada o powstaniu tej nazwy: to sam Herkules rozdzielił góry, które kiedyś połączone były w jedno pasmo, a Ocean, wcześniej zamknięty przez bryłę gór, dostał się do tych miejsc, które teraz oblewa.

(przeł. D.B. $)^{53}$

Lokalna ludność Iberii, jak podaje Strabon w omawianym fragmencie Geografii, sądzi, że w okolicy samej cieśniny nie ma niczego, co przypominałoby kolumny, a te znajdują się w mieście Gadeira. Można je identyfikować z kolumnami (a raczej stelami) we wspomnianej świątyni Heraklesa ${ }^{54}$. Stele takie oglądał Herodot, wszedłszy do świątyni w Tyrze:

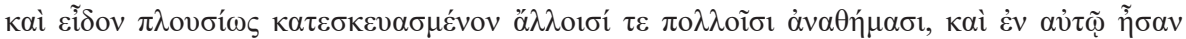

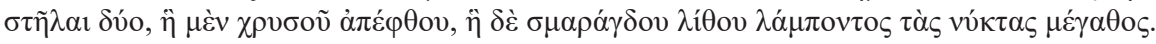

(Diod. Sic. 2.44-45).

I widziałem, jak bogato był zaopatrzony w liczne dary wotywne; między innymi były w nim dwie kolumny, jedna z czystego złota, druga ze szmaragdu, który w nocy wspaniale błyszcza ${ }^{55}$. (przekł. S. Hammer)

Tyryjska świątynia mogła być pierwowzorem tej w fenickiej kolonii. Strabon (3.5.5-6) potwierdza, że podobne stele znajdowały się w fenickiej świątyni w Gadir, ale nie uznaje ich za ,prawdziwe” Słupy Heraklesa, sądząc, że inskrypcje na stelach nie mówią nic o czynach herosa, a jedynie o wydatkach poczynionych przez Fenicjan na fundację świątyni ${ }^{56}$. Skłania się ku opinii, że kolumny

${ }^{51}$ Za wydaniem: Strab. 3.5.6 (oryginalny przekaz Pindara nie zachował się).

${ }^{52}$ Za wydaniem: Strab. 3.5.5. Cf. Amp. 7.2.

${ }^{53}$ Podobną opinię przytacza Pliniusz Starszy (HN 3.1.4) czy Seneka w Herkulesie szalejacym (Sen. HF 235).

${ }^{54} \mathrm{O}$ świętych kolumnach w Gades wspomina również Pliniusz Starszy (HN 2.242).

${ }^{55}$ Przekład z roku 2005 (s. 118).

${ }^{56}$ Vide $H N$ 2.242. Argument Strabona można łatwo obalić, gdyż nie każda budowla kultowa nosić musi imię bóstwa. Za przykład posłużyć mogą rzymskie kościoły. Inskrypcja na fasadzie 
Heraklesa były w istocie ołtarzami czy słupami granicznymi, jakie zwykli stawiać herosi czy wielcy wodzowie, jako zwieńczenie swych wypraw. Podobne słupy ustawić miał w Indiach Dionizos czy Aleksander Wielki. Dla iberyjskich kronik, o ile wspominać będą o słupach, ich funkcja jako trofeum będzie zdecydowanie najważniejsza, zaś geografia cieśniny zejdzie na drugi plan ${ }^{57}$. Dlatego też nasze rozważania zakończymy fragmentami z Diodora Sycylijskiego, który wyraźnie akcentuje tę „triumfalną”, kommemoratywną rolę słupów:

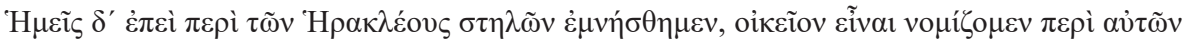

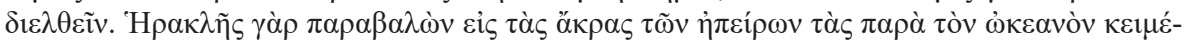

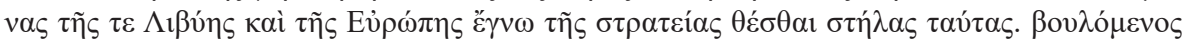

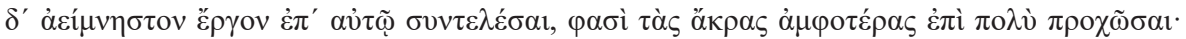

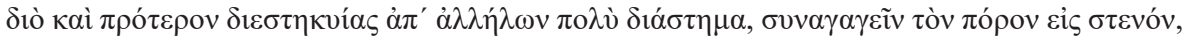

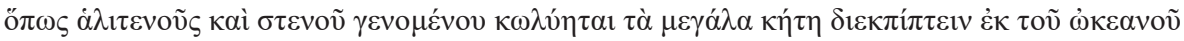

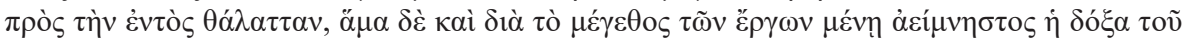

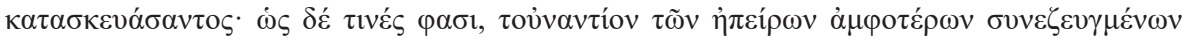

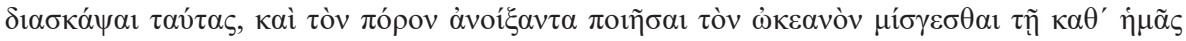

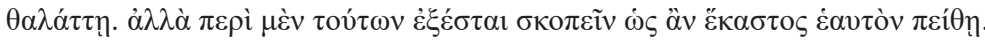

(Diod. 4.18.4-5)

Ale skoro wspomnieliśmy o słupach Heraklesa, uważamy za właściwe podanie faktów ich dotyczących. Gdy Herakles przybył do najodleglejszych punktów kontynentu Libii i Europy, które leżą nad oceanem, zdecydował ustawić słupy dla upamiętnienia swej wyprawy. A skoro pragnął zostawić na oceanie pomnik, który trwałby w wiecznej pamięci, zbudował dwa przylądki (...); w konsekwencji, podczas gdy wcześniej znajdowała się między nimi wielka przestrzeń, teraz zwęził przejście, czyniąc je płytkim i wąskim, zapobiegając tym samym, by morskie potwory przechodziły z oceanu do wewnętrznego morza (...) Niektórzy twierdzą jednak przeciwnie, a mianowicie, że obydwa kontynenty były wcześniej złączone, a on wykonał przejście między nimi, a dokonując tego sprawił, że ocean zmieszał się z naszym morzem. W tej kwestii, jednakże, każdy może myśleć, co mu się podoba.

(przeł. D.B.).

W innym miejscu Diodor przedstawia jednak zupełnie odmienną historię powstania słupów, uwzględniającą obecność kilku Heraklesów. Pierwszy słup w Libii postawić miał Herakles egipski, zaś drugi stanąć miał w Europie wiele wieków później za sprawą syna Alkmeny:

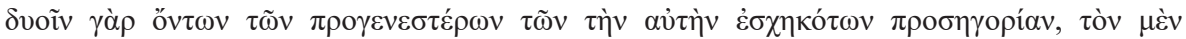

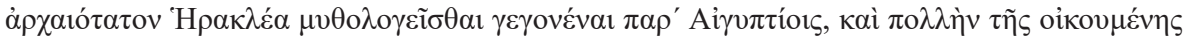

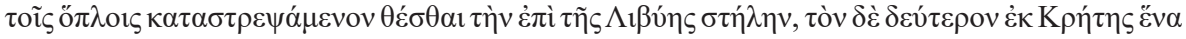

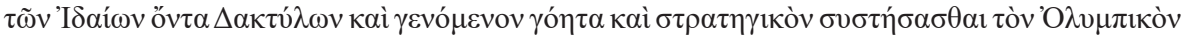

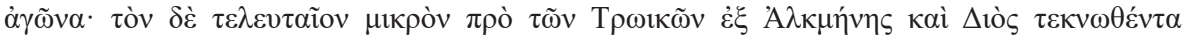

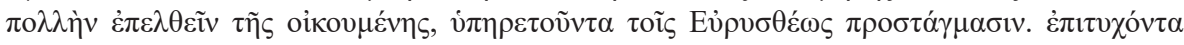

Bazyliki św. Piotra wymienia patrona oraz Pawła V, ówczesnego papieża, choć nie oznacza to, że są to bóstwa czczone w tej świątyni.

${ }^{57}$ Govers 2009: 167-170. 


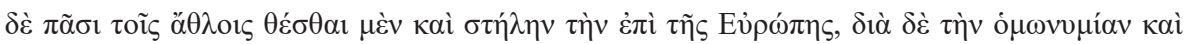

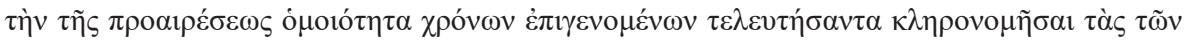

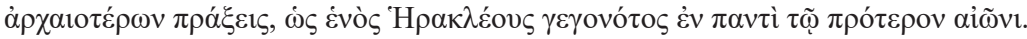

(Diod. Sic. 3.74.4-5)

W dawnych czasach były dwie postaci narodzone pod tym samym imieniem, najstarszy Herakles który, zgodnie z mitami, przyszedł na świat w Egipcie, podbił ze swym wojskiem dużą część zamieszkałego świata i ustawił słup, który jest w Libii. Drugi, który był jednym z Daktylów z góry Ida na Krecie i czarodziejem znającym się na dowodzeniu, był założycielem Igrzysk Olimpijskich; ale trzeci i ostatni, który narodził się z Alkmeny i Zeusa krótko przed wojną trojańską, odwiedził wielką część zamieszkałego świata podczas służby Eurysteuszowi, spełniając jego polecenia. A kiedy ukończył wszystkie swe prace, również postawił słup, który znajduje się w Europie; ale ponieważ nosił to samo imię, co pozostali dwaj, i żył w podobny sposób, jak oni, z biegiem czasu, po swej śmierci odziedziczył dokonania starszych o tym imieniu, tak jakby w całych dziejach był tylko jeden Herakles.

(przeł. D.B.)

Przytoczone dotąd ustępy z Diodora wykazują niekonsekwencję. Po pierwsze, fragment mówiący o przylądkach (4.18.4-5) oraz ten o walce z Gerionem (4.18.2) wyraźnie sugerują, że obydwa słupy ustawiła ta sama osoba. Po drugie, skoro to Herakles egipski miał wędrować ze swoim wojskiem i podbijać ziemie, dlaczego w ten sposób opisuje on syna Alkmeny, pogromcę Geriona (4.17.1)? Grecki Herkules powinien raczej wędrować w pojedynkę (na wzór wersji Pseudo-Apollodora). Ta niekonsekwencja autora jest chyba wyrazem bezradności wobec próby pogodzenia Heraklesa egipskiego, bezsprzecznie związanego z Gades, i drugiego, który w to samo miejsce ruszył po woły Geriona. Podobna bezradność tyczy się kwestii kolumn. Iberyjscy kronikarze otrzymają w spadku od starożytnych te wykluczające się historie i różnie będą je powtarzać, kierując się w dodatku własnymi przesłankami.

\section{RECEPCJA MITU W ŚREDNIOWICZNYCH I NOWOŻYTNYCH KRONIAKCH IBERYJSKICH}

Herkules był jeszcze w późnej starożytności bardzo popularnym bóstwem, rywalizującym z szerzącym się chrześcijaństwem i mającym najróżniejsze oblicza. Uchodził za opiekuna ubogich, w obojętności wobec śmierci stanowił wzorzec dla filozofów stoickich, jednocześnie wciąż pełniąc istotną rolę w polityce Imperium $^{58}$. W czasach Trajana i Hadriana stał się ideałem dobrego i cnotliwego władcy, a deifikację władców identyfikowano właśnie z apoteozą Herkulesa ${ }^{59}$.

\footnotetext{
${ }^{58}$ Temat ten, wraz z bibliografią, przedstawia A.I. Szoka w niewielkiej, ale wnikliwej pracy Herkules konkurent Chrystusa (Szoka 2010).

${ }^{59}$ Herakles był bóstwem opiekuńczym wodzów już w czasie Aleksandra Wielkiego, cf. Lomas Salmonte 2005: 112-113.
} 
To istotne dla naszych rozważań, gdyż iberyjscy kronikarze sięgać będą głównie po ten wzorzec greckiego herosa. Po upadku cesarstwa, w czasach Hiszpanii wizygockiej, o Herkulesie wspomina św. Izydor z Sewilli w swym encyklopedycznym dziele Etymologiarum sive Originum libri $X X$ z początków VII wieku. Mówi o kolumnach Herkulesa, twierdząc, podobnie jak Pomponiusz Mela ${ }^{60}$, że heros poniósł w Hiszpanii śmierć i tam znajduje się jego grób:

Nam Gaditanum fretum a Gadibus dictum, ubi primum ab Oceano maris Magni limen aperitur; unde et Hercules cum Gadibus pervenisset, columnas ibi posuit, sperans illic esse orbis terrarum finem ${ }^{61}$. (...) Nam postquam in Hispania Hercules interiit, et exercitus eius conpositus ex variis gentibus, amisso duce, passim sibi sedes quaerebant.

(Isid. Etym. 9.120.)

Cieśnina Gadytańska bierze swą nazwę od Gades, gdzie granica Wielkiego Morza [Morza Śródziemnego - przyp. D.B.] otwiera się na Ocean. Stąd, gdy Herkules przybył do Gades, postawił tam kolumny, wierząc, że w tym miejscu jest kraniec kręgu ziemi (...) Po śmierci Herkulesa w Hiszpanii, jego wojsko, zebrane z różnych ludów, zostawszy bez wodza, poczęło błądzić w poszukiwaniu siedziby.

(przeł. D.B.)

Wojska te, złożone między z innymi z Persów i Medów, zasiedlić miały kraj, osiadając także w Afryce Północnej, gdzie z czasem zaczęto nazywać ich Maurami. Widzimy za Izydorem, że już wczesne średniowieczne przejmuje mit Herkulesa-wodza, Hiszpanię czyni miejscem jego cywilizacyjnych dzieł. Także Słupy Heraklesa, podobnie jak w starożytności, odbierane są jako granica poznanego świata, kraniec kręgu ziemi. Na słynnej mapie Tabula Peutingeriana (trzynastowiecznej kopii mapy antycznej) w okolicy Gibraltaru widać rzeczywiście dwie białe kolumny oznaczone jako „Columne Ercole”. Kopista namalował je przed cieśniną jakby na wyspie, sugerując - o ile ich wizerunek nie jest czysto symboliczny - że obydwie znajdowały się wówczas w Kadyksie. Na szesnastowiecznej rycinie przedstawiającej połów tuńczyka w Kadyksie, widzimy, że sieci przymocowano do dwóch wielkich wież ${ }^{62}$ (Ryc. 2). Formowały one część

${ }^{60}$ Pomponiusz Mela (3.46) miał tutaj na myśli Herkulesa egipskiego, którego odróżniał od tebańskiego. Według powszechnej tradycji, przyjętej przez Melę, ten drugi zginąć miał w Tesalii na szczycie góry Ojte (Mela 2.36). Izydor raczej nie znał Chorographii z pierwszej ręki i bazował na dziełach Pliniusza Starszego oraz kompilatorze Solinusie z III-IV wieku. Wzrost zainteresowania Chorographiq Meli nastąpił w XIV wieku, gdy Petrarka zamówił kopię rękopisu z Awinionu i zainteresował dziełem włoskich humanistów. Drukiem dzieło wydano w 1471 w Mediolanie, a pierwszego thumaczenia na hiszpański dokonał José Antonio González de Salas w 1644 roku. W czasach wczesnośredniowiecznych dzieło krążyło w rękopisach i było znane, podobnie jak dzieło Pliniusza Starszego, który powoływał się na Melę. Najstarszy zachowany rękopis pochodzi z IX wieku, cf. Szarypkin 2011: 33.

${ }^{61}$ Cf. Isid. Etym. 13.15.

${ }^{62}$ Tytuł mapy to La almadraba de Hércules en Cádiz, según el grabado de Hoefnagel para el Ciuitates Orbis Terrarum, cf. Corzo Sánchez 2005: 117. Połowy takie przeprowadzano już w starożytności i mogły być związane z rytuałem topienia i palenia wizerunku Melkarta. 


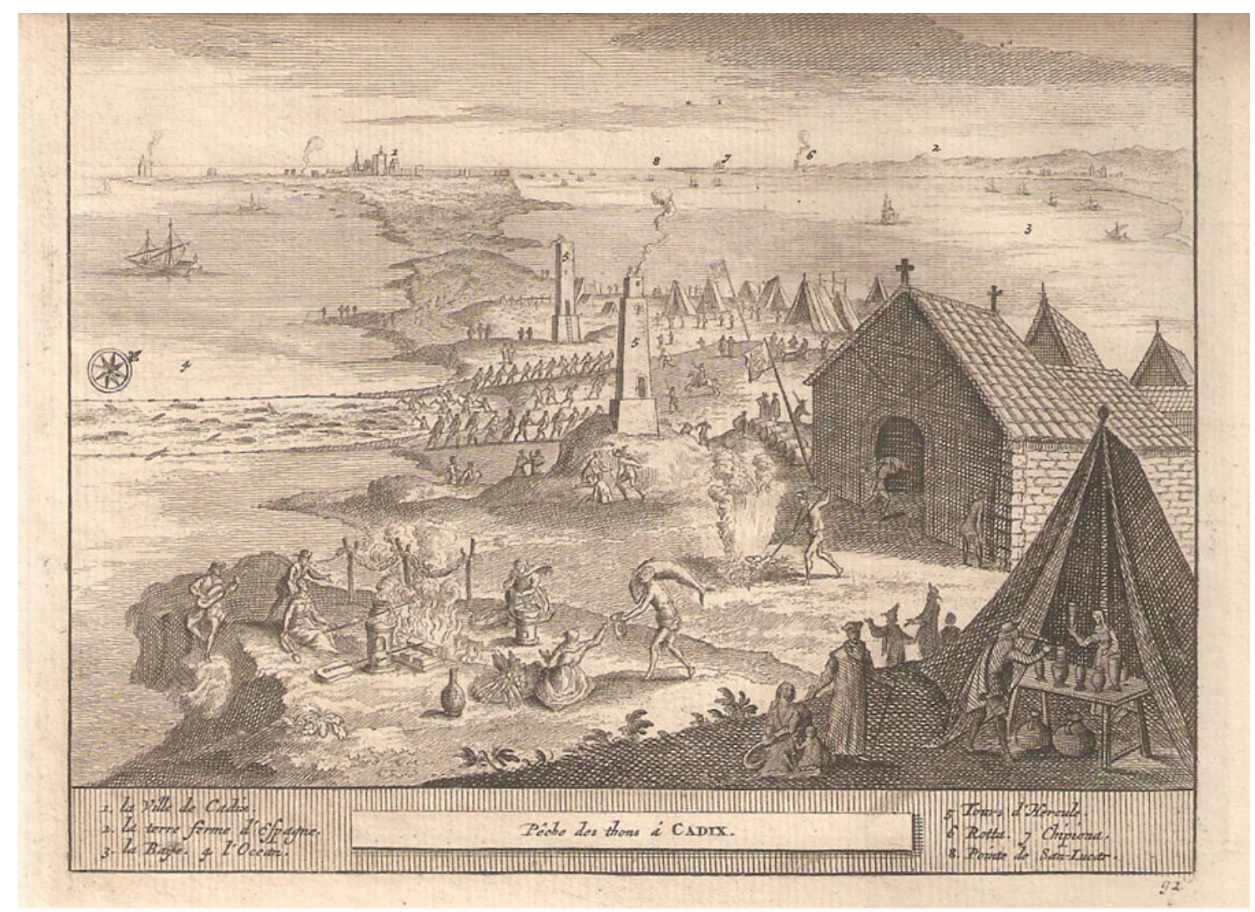

Ryc. 2. Połów tuńczyka w Kadyksie i Wieże Herkulesa. Captura de Atún en Cádiz z dzieła Les Delices de L'Espagne et du Portugal, Juan Álvarez de Colmenar, miedzioryt z 1715 .

Źródło: [https://www.grabadoslaurenceshand.com/vista-de-la-almandraba-cadiz] (dostęp 13.03.2018).

rybackich zabudowań, tzw. Almadraba de Hércules, a połowów dokonywano tutaj już w czasach fenickich. W średniowieczu miejsce to podupadło, jednak w XVII wieku wznowiono połowy, a umocnione odtąd wieże pełniły cele obronne i służyły jako latarnie morskie. Wieże te są widoczne na siedemnastowiecznych rycinach i mapach ${ }^{63}$, a do dziś w Kadyksie zachowała się jedna z nich zwana Torregorda (,gruba wieża” ${ }^{64}$.

Już pod panowaniem arabskim w Al-Andalus ciekawy passus Herkulesowi poświęca Kronika Maura Al-Rasiego. Zauważmy, że - podobnie jak u Diodora Sycylijskiego ${ }^{65}$ - Herkules udaje się do Hiszpanii wyłącznie w celu jej podbicia i zaludnienia:

\footnotetext{
${ }^{63}$ Autorami map, na których widać wieże Herkulesa są: N.J. Visscher (1660, detal na mapie Półwyspu Iberyjskiego), Allard (1713) i Juan Álvarez de Colmenar (1715). Są podpisane jako wieże lub kolumny Herkulesa.

${ }^{64}$ Więcej o wieży w Torregorda: Ortega Feliu, Aladro Prieto 2012.

${ }^{65}$ Kompletne dzieło Diodora dotrwało aż do złupienia Konstantynopola w 1453. Najwcześniejszy zachowany rękopis pochodzi z X wieku. Dopiero 1472 dokonano w Bolonii pierwszego
} 
Ercoles, quando sopo nuevas que España era poblada, aguiso sus conpañas e basteçio sus naves e veno para España. E el primero logar a que aportaron fue el puerto de Calid, aquel que después el poblo e fizo los conçilios. E Ercoles, andando por España a su voluntad e catando que tierra era, salió a el el rrey de España, lidio con Ercoles e con los griegos, e fue tal su ventura que lo mato Ercoles. E aquel fue el postrimero rrey de los cinquenta y tres rreyes que vos agora fablamos que vienen de Espan E esta lid fue a tres migeros de la cibdat que agora llaman la Curuña ${ }^{66}$.

(Crónica del moro Rasis... 1975: 889-955, pisownia oryginalna)

Herkules, gdy dowiedział się, że Hiszpania była zaludniona, zebrał swoje oddziały, zaopatrzył swe okręty i przybył do Hiszpanii. A pierwszym miejscem, do którego przybili, był port w Ca$l_{1}{ }^{67}$, który on sam później zaludnił i założył zgromadzenie. A gdy Herkules chodził zgodnie ze swą wolą po Hiszpanii i patrzył, co to była za ziemia, wyszedł na niego król Hiszpanii [tj. Gerion - przyp. D.B.], walczył z Herkulesem i z Grekami, a spotkał go taki los, że Herkules go zabił. I był to ostatni z 53 królów, o których wam teraz mówimy, którzy pochodzą od Espana. Walka ta miała miejsce trzy mile od miasta, które teraz nazywają la Curuña.

(przeł. D.B.)

Zauważmy, że wydźwięk relacji Al-Rasiego jest już typowo wojenny, jak u Diodora Sycylijskiego. O ile ten ostatni wspominał jeszcze szczątkowo o uprowadzeniu wołów, Al-Rasi zupełnie pomija ten wątek. Walka z Gerionem rozgrywa się w Galicji, a autor nie wspomina już o Erythei, ani żadnej wyspie, jak starożytni. W przedstawieniu postaci Herkulesa autor zupełnie odchodzi od tradycji antycznych. W jednym miejscu nazywa Herkulesa pierwszym i największym królem greckim (sic!). Miał być nastawiony na ekspansję i nie było ziemi, która nie dostałaby się pod jego władzę. Kronikarz wskazuje też, że Herkules po 29 latach panowania, spoczął w hiszpańskim mieście Estorga (w czym różni się od Pomponiusza Meli, który lokował jego grób w Gades). Po śmierci wodza Grecy wybrali następcą jego syna o imieniu Latin. Kolejni kronikarze następcą Herkulesa czynić będą jednak nie Latina, lecz Espana (Hispana). W przekazie Al-Rasiego jest on protoplastą... Geriona. Autor milczy także na temat kolumn Herkulesa, mówiąc za to o wizerunkach byków, koni i kozłów, które heros stawiał jako symbole swej władzy i które czczono w jego czasach ${ }^{68}$.

Ciekawą relacją, w której znajdujemy informacje o Słupach Heraklesa jest Liber Sancti Jacobi (Kodeks Kalikstyński z 1130 r.), słynny średniowieczny przewodnik dla pielgrzymów do Santiago de Compostela. Mówi on o kolumnie,

wydania po łacinie. W hiszpańskim Eskorialu znajdują się dwa rękopisy. Pierwszy (Scorialensis Y I.2) wykonany w Wenecji dla Diego de Mendozy w 1542, drugi (Scorialensis $\Sigma$ III.5), który Angelo Giustiniani zostawił Filipowi II pod koniec XVI wieku.

${ }^{66}$ Crónica del moro Rasis... 1975: 889-955. Kronika została przełożona na język romański dla króla Portugalii Dionizego I ok. 1300 r., cf. A. Vigo Trasancos 2010: 218.

${ }^{67} \mathrm{Tj}$. Cádiz (Kadyks). W średniowieczu miasto błędnie nazywano Calid lub Caliz (od łac. calix, kielich).

${ }^{68}$ Vigo Trasancos 2010: 218. Al-Razi wylicza, że w czasie gdy Herkules przybył do Hiszpanii, był 2995 rok ery Adama, zaś Espan był według niego synem Jafeta, wnukiem Noego. 
a raczej skale zwieńczonej idolem, którego szczególnie obawiali się Arabowie, nazywając go „Salam de Cadiz”. Skała miała być zwieńczona brązowym wizerunkiem człowieka trzymającego olbrzymi klucz. Saraceni wierzyli ponoć, że gdy klucz upadnie, narodzi się w Galii król, który całą Hiszpanię pozyska dla chrześcijan (w kodeksie tym mowa o Karolu Wielkim) ${ }^{69}$. Jeśli przyjąć, że kronikarze mówią o konkretnej kolumnie, można postawić pytanie czy mogłaby ona przetrwać od starożytności aż do czasów panowania arabskiego. Przykład latarni w egipskiej Aleksandrii (która przetrwała do trzęsienia ziemi w XIV w.) wskazuje, że było to możliwe. Warto dodać w tym miejscu nieco więcej o związkach Herkulesa z Santiago de Compostela, które od IX wieku było ośrodkiem kultu św. Jakuba. W portalu katedry zwanym Pórtico de la Gloria, przedstawiającym Chrystusa Pantokratora w otoczeniu apostołów, znajduje się w podstawie postać brodatego mężczyzny (którego uczeni utożsamiają z Herkulesem) ${ }^{70}$ trzymającego po bokach dwa lwy. Choć portal powstał w XIII wieku, odzwierciedla on być może jeszcze pojmowanie Herkulesa, będącego uosobieniem całej pogańskiej przeszłości Hiszpanii. Przedstawiony nad nim św. Jakub Apostoł, legendarny ewangelizator Hiszpanii, symbolizuje z kolei nową erę, czasy chrześcijaństwa.

Ważną kroniką chrześcijańską, wspominającą o wyprawie Herkulesa i jego słupach jest De rebus Hispaniae (ok. 1243), której autorem jest Rodrigo Jiménez de Rada „El Toledano”, trzynastowieczny historyk, arcybiskup Toledo. De Rada w swej kronice wskazuje jasno, że Herkules przybył do Hesperii, gdzie zbudował port dla swoich statków oraz solidne wieże (zachowane do czasów autora) zwane Gades de Hércules ${ }^{71}$. El Toledano podkreśla jednak głównie rolę następcy Herkulesa, Hispana, mądrego króla, od którego nazwę wzięła Hispania (dotąd nazywana Hesperią). Herkulesa za to przedstawia niezbyt pozytywnie jako sprawcę licznych zniszczeń, odkupionych dopiero przez Hispana ${ }^{72}$. Mimo to Herkulesa czyni kronikarz założycielem dynastii, ustanawiając więź między światem antycznym i kastylijską linią królewską.

Monarchia kastylijska wykazuje od XIII wieku szczególne zainteresowanie postacią Herkulesa. Polityce rekonkwisty i jednoczenia rozbitych królestw odpowiada mit trójgłowego Geriona ${ }^{73}$, władającego trzema oddzielnymi królestwami, które Herkules i Hispan jednoczą. Hispan nosi oczywiście cechy dobrego króla: jest sprawiedliwy i kochany przez lud. Kroniki tego okresu będą przytaczać również osobę Juliusza Cezara, odwołując się do antycznej, rzymskiej

${ }^{69}$ Liber Sancti Jacobi... 1951: 415-416.

${ }^{70}$ Vigo Trasancos 2010: 225. Herkules z dwoma lwami widnieje w herbie Kadyksu i Andaluzji (cf. Ryc. 2-3).

${ }^{71}$ Jiménez de Rada 1989: 66-71.

${ }^{72}$ Jiménez de Rada 1989: 66-71. Cf. Vigo Trasancos 2010: 218; Valverde 1989: 46.

${ }^{73} \mathrm{~W}$ kontekście polskim nasuwa się tutaj skojarzenie z rozczłonkowanym ciałem św. Stanisława, które porównywano do rozbicia dzielnicowego, zaś jego zrośnięcie symbolizować miało nadzieję na zjednoczenie królestwa. 
jedności Hiszpanii ${ }^{74}$. Tendencja ta pojawia się zwłaszcza w czasach Alfonsa $\mathrm{X}$, będącego fundatorem wspomnianego Pórtico de la Gloria i jednocześnie inicjatorem oraz autorem kroniki Estoria de Espanna (1274-1289). Dzieło to powstało w kilku wersjach i było systematycznie uzupełniane przez kolejnych kronikarzy, składając się na monumentalną General Estoria ${ }^{75}$. W IV rozdziale kronika ta wyróżnia trzech Herkulesów. Dwaj pierwsi są pochodzenia greckiego, jeden znany ze swych czynów (nieopowiedzianych w historii), drugi przez swoją mądrość. Kronika posługuje się chronologią biblijną i datuje pierwszych Herkulesów na epokę Mojżesza. Trzeciego Herkulesa kronika uznaje za syna Jowisza i Alkmeny. Dokonać miał bardzo wielkich czynów, o których mówi cały świat, był największym i najodważniejszym z ludzi, a jego narodzenie i dokonania były zapowiedziane przez mędrców greckich. O nim pisali też wszyscy dawni kronikarze ${ }^{76}$. Historię o interesującej nas wyprawie rozpoczyna opis poprzednich dziewięciu prac, po czym Herkules rusza w podróż przez Libię, skąd miał przedostać się do Hiszpanii:

Hercules (...) ovo diez naves e metios en mar, e passo dAffrica a Espanna (...) arribo a una ysla o entra el mar Mediterraneo en el mar Oceano; e por quel semeio que aquel logar era muy vicioso y estava en el comienco doccidente, fizo y una torre muy grand, e puso ensomo una ymagen de cobre bien fecha que catava contra orient e tenie en la mano diestra una grand llave en semeiante cuemo que querie abrir puerta, e la mano siniestra tenie algada e tenduda contra orient e avie escripto en la palma: estos son los moiones de Hércules. E por que en latin dizen por moiones Gades, pusieron nombre a la ysla Gades Hercules, aquella que oy en dia llaman Caliz.

(Alfonso X 1906: 8), pisownia oryginalna

Herkules (...) miał dziesięć okrętów i wypłynął nimi w morze i przeprawił się z Afryki do Hiszpanii (...) przybył na pewną wyspę, gdzie Morze Śródziemne wpada do Oceanu. A ponieważ tamto miejsce wydało mu się bardzo pustynne i znajdowało się na krańcu zachodnim, zbudował bardzo dużą wieżę. Na niej ustawił wizerunek z brązu, dobrze wykonany, który był zwrócony na wschód i trzymał w prawej ręce wielki klucz, tak jakby chciał otworzyć drzwi. A lewą rękę miał wzniesioną i wyciągniętą na wschód, a na dłoni było napisane: to są słupy Heraklesa [hiszp. mojón, łac. mutulus, tu jako słup graniczny - przyp. D.B.]. A jako, że po łacinie nazywają słupy Gades, nadano wyspie nazwę Gades Herkulesa, tej wyspie, którą dziś nazywa się Caliz.

(przeł. D.B.)

\section{${ }^{74}$ Cagan 2010: 54-55.}

${ }^{75}$ Jest to oczywiście dzieło kompilacyjne, a poza mitologią i dawnymi historykami czerpie obficie z Biblii. Jako główne źródła wskazuje się Kanony Euzebiusza z Cezarei, Metamorfozy i Heroidy Owidiusza, Historię naturalna Pliniusza, Farsalia Lukana oraz Antiquitates Józefa Flawiusza, Etymologie Izydora, a nadto źródła brytyjskie, francuskie, arabskie i żydowskie.

${ }^{76}$ Alfonso X 1906: 7. Interesujące nas części kroniki to rozdział IV (o trzech Herkulesach), rozdział V (Herkules w Kadyksie i Sewilli), rozdział VI (czego dokonał Juliusz Cezar, a czego Herkules nie zdołał), rozdział VII (walka z Gerionem), rozdział VIII (o miastach założonych przez Herkulesa). Kolejne opowiadają już o królu Espanie i jego następcach. 
Kolosa, stojącego na wieży znamy już z Kodeksu Kalikstyńskiego ${ }^{77}$. Pewnym novum jest historia o statkach, na których Herkules przepłynął cieśninę, bliska wersji Diodora Sycylijskiego, daleka z kolei od Pseudo-Apollodora ${ }^{78}$. Po ustawieniu wieży w Kadyksie, Herkules rusza z nurtem Gwadalkiwiru, jednak wstrzymuje się z założeniem Sewilli, gdyż według przeznaczenia rola ta przypaść ma jego dalekiemu następcy, Juliuszowi Cezarowi. Toteż poprzestaje na wzniesieniu sześciu filarów oraz tablicy z inskrypcją AQUI SERA POBLADA LA GRANT CIBDAT („tu zasiedli się wielkie miasto") ${ }^{79}$. Następnie podążył Herkules do siedziby Geriona przez Lizbonę (założoną przez wnuka Ulissesa o tym samym imieniu i jego córkę Bonę, co dało nazwę Lixbona) ${ }^{80}$.

Gerion w kronice Alfonsa X jest gigantem, złowrogim królem Hesperii, o którym ,ponieważ miał w swej władzy siedem prowincji, mówiło się w dawnych podaniach, że miał siedem głów" (jakie to antyczne podania mówiły o siedmiogłowym Gerionie, autor nie wspomina, chcąc raczej dopasować ilość głów do liczby prowincji). Swoim poddanym zabiera połowę majątku, a nadto synów i córki, pod groźbą śmierci. Słysząc o wspaniałych czynach Herkulesa, lud wzywa go na pomoc, w zamian ofiarując swą ziemię w posiadanie (znów ani słowa o wołach). Gerion, na wieść o nadchodzącym Herkulesie zbiega na północ. Obydwaj wodzowie dysponują armią, jednak decydują się na pojedynek. Oto fragment z rozdziału VII:

E quando Gerion lo sopo, fuesse con sus huestes pora aquel logar o fue despues poblada la cibdat que dizen Crunna, que era estonce yermo. Hercules envio dezir a Gerion que las yentes no avien por que matarse ni por que lazrar, mas que lidiassen ellos amos un por otro; y el que venciesse, que fuesse toda la tierra suya. E Gerion atreviendose en su valentia, e demas que era mayor que el, dixo quel plazie. E lidiaron tres dias que nos podien vencer; en cabo vencio

${ }^{77} \mathrm{~W}$ rozdziale $\mathrm{V}$ autor mówi o jednej wieży, zaś w rozdziale VIII o dwóch słupach, na których Herkules zbudował wizerunek („los pilares sobre que pusiera Hercules la imagen”), Alfonso X 1906: 9.

${ }^{78}$ Tekst Biblioteki Pseudo-Apollodora w czasach średniowiecznych nie był zbyt dostępny i można podejrzewać, że iberyjscy kronikarze początkowo go nie znali. W XIII wieku istniał on tylko w jednym egzemplarzu, który skopiowano dopiero w XV wieku dla kardynała Bessariona, a opublikowano w Rzymie (1555) i Heidelbergu (1559).

${ }^{79}$ Alfonso X 1906: 10. Przyszłość tę przepowiedział Herkulesowi wędrujący z nim Allas (Atlas), mędrzec i astrolog. W XVI wieku na jednej z jednej z bram Sewilli, Puerta de Jerez, zawiśnie tablica z czterowierszem: „Hercules me edifico / Julio Cesar me cerco / de muros y torres altas / El Rey santo me gano / con Garci Perez de Vargas" (Zbudował mnie Herkules, Juliusz Cezar otoczył mnie murem i wysokimi wieżami. Święty król mnie zdobył, dzięki Garcii Perezowi de Vargas), cf. Domínguez Arjona 2000 [http://www.galeon.com/juliodominguez/puertajerez.htm], dostęp 15.10.2016. W rozdziale VII kronika, powołując się na Lukiana, opowiada historię o wizycie Cezara w świątyni Herkulesa.

${ }^{80} \mathrm{Za}$ wydaniem: Alfonso X 1906: 9. 
Hercules, e cortol la cabeca. E mando en aquel logar fazer una torre muy grand. E fizo meter la cabeça de Gerion en el cimiento ${ }^{81}$.

(Alfonso X 1906: 12), pisownia oryginalna

Gdy dowiedział się o tym Gerion, odszedł ze swymi wojskami do miejsca, w którym później powstało miasto nazywane Crunna, które wówczas leżało odłogiem. Herkules posłał, by powiedzieć Gerionowi, że ludzie nie powinni ginąć ani cierpieć, ale by walczyli tylko oni dwaj, jeden z drugim; a kto wygra, tego będzie cała ziemia. A Gerion, chełpiąc się swą odwagą, a ponadto będąc większym od niego, przystał na to. I walczyli trzy dni, nie mogąc zwyciężyć. Ostatecznie zwyciężył Herkules, i uciął mu głowę, i rozkazał uczynić tam wielką wieżę. I kazał położyć głowę Geriona w jej fundamentach.

(przeł. D.B.)

Herkules zakłada miasto i nazywa je od pierwszej przybyłej na zasiedlenie kobiety, imieniem Crunna ${ }^{82}$. Zauważmy, że Słupy Herkulesa w cytowanej kronice wznoszą się nie po obu stronach Cieśniny Gibraltarskiej (jak wskazują wszystkie niemal źródła antyczne), lecz na przeciwległych krańcach Hiszpanii: w Kadyksie i A Coruñi. Kronikarze kastylijscy, wskazujący na Herkulesa jako zdobywcę ziem całej Iberii, świadomie przesuwają lokalizację słupów, podkreślając istotne $w$ ich czasach idee rekonkwisty i zjednoczenia. Umyślnie utożsamiają więc mityczne kolumny z rzeczywiście istniejącymi wieżami czy latarniami morskimi, choć żadne źródło antyczne nie definiowało ich w ten sposób. U autorów starożytnych nie istniały wzmianki o związkach Geriona z północną Iberią. Pliniusz Starszy (4.22.120), a także Pomponiusz Mela wskazują co prawda, że Erytheia znajdować się mogła w Luzytanii, a więc na północ od miasta Gades, z pewnością jednak nie na samej północy półwyspu:

In Lusitania Erythia est quam Geryonae habitatam accepimus, aliaeque sine certis no minibus ${ }^{83}$. (Mela 3.6.47.)

Erythia jest w Luzytanii, zamieszkana, jak przyjmujemy, przez Geriona oraz inne wyspy bez ustalonych nazw.

(przekł. aut.)

${ }^{81}$ Pauzaniasz twierdził, że grób Geriona znajdował się w Kadyksie (Gadejra), na przekór mieszkańcom Lidii, uważającym, że i oni posiadają jego kości. Cf. Paus. 1.35.7-8.

${ }^{82} \mathrm{Za}$ wydaniem: Alfonso X 1906:10. Według niektórych teorii nazwa miasta może pochodzić od Kronosa, którego, podobnie jak Herkulesa, łączonego z krańcem świata. Salvador Bravo Jiménez (Bravo Jiménez 2014: 96-98) omawia ewolucję mitycznego konceptu „Bram Kronosa” do „Kolumn Melkarta”. Dawne, błędne etymologie wyprowadzały nazwę miasta od „kolumny” (Agra Bernadal 2018).

${ }^{83}$ Mela nie wymienia w Opisaniu świata A Coruñi (łac. Brigantium). Luzytania według niego (3.6) zaczyna się już za rzeką Anas, czyli Gwadalkiwirem. Można domniemywać, że lokalizował on Eryteję na obecnym wybrzeżu portugalskim, ale nie na ziemiach Galicji, które nazywa celtyckimi (3.9-10). O wędrówce Heraklesa do kraju Celtów wspomina Parthenios z Nikozji (Parth. Amat. narr. 30). 
Cała przedstawiona historia znajduje swoje odzwierciedlenie w używanych do dzisiaj herbach Kadyksu i A Coruñi (Ryc. 3 i 4). Na pierwszym z nich Herkules widnieje w lwiej skórze, trzymając dwa lwy (symbolizujące Europę i Afrykę), a towarzyszy mu motto HERCULES FUNDATOR GADIUM DOMINATORQUE (łac. „Herkules założyciel i pan Kadyksu”). Z kolei w herbie galicyjskiej A Coruñi od 1521 roku znajduje się latarnia, Wieża Herkulesa, u podstaw której widzimy odciętą głowę bądź czaszkę Geriona ${ }^{84}$. Herkules założył później jeszcze inne miasta, m.in. Tarazonę, la Seu d'Urgell czy Barcelonę (do której trafił dziewiątym statkiem, pozostałe zostawiając po drodze, stąd domniemana etymologia Barca nona) ${ }^{85}$. Później zdecydował odejść, by podbijać inne ziemie, a w Hesperii pozostawił greckiego pochodzenia ludzi, na których czele stanął jego bratanek Espan. To on zaludnia Kadyks, w którym Herkules zdążył tylko ustawić kolumnę i montuje lustro na wieży w A Coruñi, służące ochronie przez najeźdźcami. Ma to odzwierciedlenie w hiszpańskiej historii, gdyż to właśnie Alfons X, autor kroniki, odzyskał Kadyks z rąk arabskich (1262) i uczynił go ważnym miastem handlowym ${ }^{86}$. Autor podkreśla, że Espan zyskiwał sobie władzę nie poprzez siłę, jak Herkules, ale przez miłość. Ten mityczny bohater staje się uosobieniem cnót oraz rzeczywistych osiągnięć władcy. Przeciwstawienie niszczycielskiej siły Herkulesa (antycznej) i sprawiedliwej dobroci Espana (chrześcijańskiej) odzwierciedla też wspomniany Portal de Gloria. Widzimy, że Estoria de Espanna, podobnie jak inne średniowieczne kroniki mieszają fałszywe i prawdziwe narracje, legendy i fakty historyczne. Zmyślonych postaci nie można zrównywać z historyczną nierzetelnością czy błędem, to świadoma działalność autora. Ostatecznym wyznacznikiem kroniki nie jest odniesienie do rzeczywistości, ale intencje twórcy ${ }^{87}$.

Kolejne przekazy kronikarskie, którym się przyjrzymy, powstały w Hiszpanii już po rekonkwiście i zjednoczeniu dynastycznym, w Koronie, która stać się miała kolonialnym imperium. Będzie to miało wpływ na wizerunek Herkulesa i słupów. W okresie między Alfonsem X Mądrym, a rządami Jana II Kastylijskiego, ojca słynnej Izabeli Katolickiej, starano się jeszcze wpisać dzieje narodu w uniwersalny ciąg dziejów. W XV w. zacznie się to jednak zmieniać: pojawią się tendencje „romantyczne” w przedstawianiu historii. Ówcześni kronikarze nie

\footnotetext{
${ }^{84}$ Owa wieża, Torre de Hércules, istniejąca do dziś w La Coruñi, to w istocie rzymska latarnia morska z czasów Trajana, choć jej popularna nazwa nadal jest w użyciu. Więcej na ten temat w dwutomowej pracy Hércules contra Gerión (González García 1997).

${ }^{85}$ Także kataloński kronikarz Jeroni Pujades, opisując topografię Barcelony w swej Coronica Universal del Principat de Cathalunya z 1609 roku stwierdza na przykład, że jeden z dawnych zamków przy ulicy Call określa się mianem „Castillo de Hércules” (t. 7, 14.34). W innym miejscu (t. 7, 15.2) sugeruje, że pozostałości rzymskie w ogrodzie na Mont Tàber niektórzy uznawali za grób Herkulesa, cf. Pujades 1831: 235, 397.

${ }^{86}$ Vigo Trasancos 2010: 218-220. Estoria de Espanna jest bogato ilustrowana, a miniatury przedstawiają też Herkulesa. Jego postać trafia też do sali królewskiej Alkazaru w Segovii.

${ }^{87}$ Córdoba 1985: 237.
} 


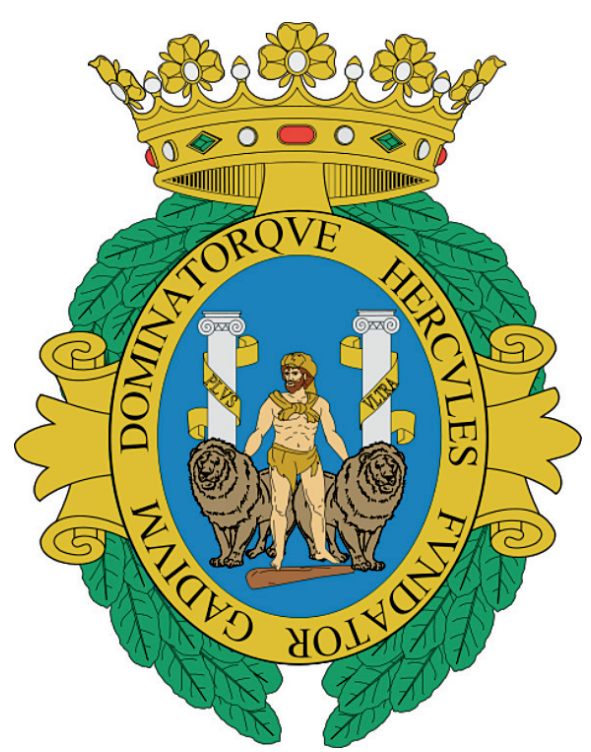

Ryc. 3. Herb miasta Kadyks z Herkulesemzałożycielem i kolumnami z napisem PLUS ULTRA.

Źródło: [https://commons.wikimedia.org/wiki/ File:Escudo_de_Cádiz_(oval).svg] (dostęp 12.03.2018)

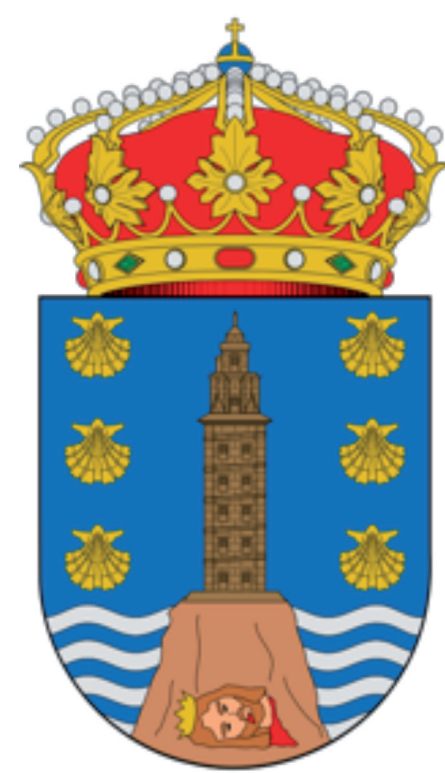

Ryc. 4. Herb hiszpańskiej prowincji A Coruña z Wieżą Herkulesa i głową Geriona w fundamencie.

Źródło:[https://commons.wikimedia.org/wiki/ File:Escudo_de_la_provincia_de_A_Coruña. svg] (dostęp 12.02.2018)

będą chcieli już wywodzić historii Hiszpanii ze starożytności, lecz wywyższać Kastylię i wykazać starodawność jej autochtonicznej kultury ${ }^{88}$. Będą twierdzić, że kultura kastylijska przewyższa grecką, kładąc nacisk na panowanie plemion gockich. Przykładem może być powszechność romansów, średniowiecznych pieśni z XIV-XV wieku, w których można jeszcze znaleźć echa czynów Herkulesa. W jednym z utworów mowa o królu Roderyku, każącym złamać łańcuchy broniące wejścia do jaskini w okolicach Toledo, uchodzącej za dom Herkulesa, który „pierwszy zdobył Hiszpanię, z rąk Geriona, wielkiego tyrana”»9. W tym

${ }^{88}$ Nawrócony Żyd, poeta i biskup Burgos, Pablo de Santa María, w dziele Siete edades del mundo zgodził się co do Herkulesa-założyciela dynastii, ale zmienił jego imię na Gedeona. Pominął okres rządów Kartagińczyków i Rzymian, a skupił się na Gotach i okresie rekonkwisty. Mówił o Kastylii, a nie prowincji rzymskiej, odnosząc się do Starego Testamentu, nie zaś mitologii. Później Rodrigo Sánchez de Arévalo, jego intelektualny spadkobierca, napisze, że Kastylia istniała „jako duchowe serce Hiszpanii na długo przed zburzeniem Troi, i że byli tam królowie na długo przed Gerionem". Cf. Grieve 2009: 73-74.

${ }^{89}$ Pieśni nr 583 i 584 (Durán 1849: 400-401). Tę samą historię przytacza Gutierre Díaz de Games w V rozdziale El Victorial, crónica de don Pero Niño, Conde de Buelna (Díaz de Games 1940: 29). 
czasie widzimy pojawienie się tzw. Herkulesów narodowych, jak Hercules Germanicus, jeden z tytułów cesarza Maksymiliana I ${ }^{90}$.

Niemniej jednak pod koniec XV w. Gualberto Fabricio de Vagad w Crónica de Aragón (1499), otwarcie apeluje do historyków, by nie otwierali kronik mitem o Herkulesie, gdyż daje to złe wrażenie początków hiszpańskiej historii. Ów benedyktyn mówi wprost, że Homer przewracałby się w grobie, gdyby wiedział, ile wspaniałych czynów dokonali starożytni Hiszpanie (sic!), przyćmiewając dokonania Trojan i Argiwów z Iliady ${ }^{91}$. Dla Giovanniego Nanniego (Annio de Viterbo), włoskiego dominikanina i fałszerza dokumentów (Antiquitatum variarum volumina XVII cum comentariis z 1498), Herkules jest już tylko piratem, ostatnim z prymitywnych dawnych królów, nie zaś założycielem nowej dynastii ${ }^{2}$.

Mimo tych nacjonalistycznych tendencji, to właśnie we wczesnej nowożytności kronikarze tacy jak Florián de Ocampo czy Ambrosio de Morales w Crónica General de España usuną w cień greckiego, a nawet tyryjskiego Herkulesa, stawiając na jego miejsce jeszcze starszego egipskiego Herkulesa-Horusa ${ }^{93}$. Ambrosio de Morales, kronikarz Filipa II, w pierwszym tomie Crónica General (1574) dochodzi do wniosku (podobnie jak Hekatajos z Miletu), że grecki Herkules $\mathrm{w}$ istocie nigdy nie dotarł do Hiszpanii, a nawet jeśli dotarł, to zatrzymał się tylko na wybrzeżu morskim, zakładając osadę przy Gibraltarze:

Aquel es el que los coronistas antiguos por otro nombre llamaron Hercules el Egipciano, y Hercules el Grande, por diferenciarle de muchos Hércules no tan señalados por, que tuviéron otras tierras: y particularmente de Hércules Griego, natural de la ciudad de Tebas, llamado Alceo, y por otro nombre Iraclis, hijo de (...) Anfitrion, y de Alcmena, su muger ${ }^{94}$.

Jest to ten, którego dawni kronikarze nazywali Herkulesem Egipskim albo Wielkim, by odróżnić go od innych Herkulesów, nie tak znaczących, z innych ziem, a zwłaszcza od Herkulesa Greckiego, narodzonego w Tebach, zwanego Alkajosem lub Iraklisem, syna (...) Amfitriona i Alkmeny (przeł. D.B.).

${ }^{90}$ Banach 1984: 62

${ }^{91}$ Tate 1970: 24.

${ }^{92} \mathrm{~W}$ swoim dziele doszukiwał się on dawnych, jeszcze starotestamentowych dziejów Hiszpanii i Francji, uświetniając ich linie dynastyczne. Przypisywał założenie Hiszpanii Tubalowi, piątemu synowi Jafeta (wiedzę swą czerpać miał z apokryfów przypisanych autorytetowi Berossosa, kapłana babilońskiego z czasów Aleksandra Wielkiego, cf. Caballero López 2002: 100-120; Córdoba 1985: 248-249).

${ }^{93}$ Autorzy ci wzorować się będą na fikcyjnej liście królów hiszpańskich, jaką stworzył Giovanni Nanni de Viterbo w 1498, cf. Camacho 2016: 197; Hernández de la Fuente 2012: 80, cf. Eus. Chron. 1.44. Portugalczyk Bernardo de Brito w swej Monarchia Lusitana opisuje przybycie do Hiszpanii najpierw Herkulesa Libijskiego i walkę z Gerionem, którą datuje się na 1718 p.n.e. (rozdz. 10-12), a później dopiero Herkulesa Greckiego (rozdz. 19) w roku 1309 p.n.e.

${ }^{94}$ Morales 1791: 92-93, pisownia oryginalna. W rozdziale XIII autor powołuje się na Arriana, jednak obala jego teorię, że przybyły do Hiszpanii Herkules pochodził z Tyru. 
Tenże Alkajos (Herkules Tebański) przywłaszczyć miał sobie imię Herkulesa Libijskiego czy Egipskiego, otrzymując za swoje zasługi imię dawniejszego boga, przez co był mylony przez kronikarzy iberyjskich. Ocampo i Morales dochodzą nawet do wniosku (ignorując zdanie Herodota i Arriana), że Herkules-założyciel Hiszpanii jest starszy od Tyru! Jego historię poprzedzają bowiem dzieje Ozyrysa-Dionizosa, który był jego ojcem. Jak czytamy w rozdziałach XI i XII pierwszego tomu, ów kapitan egipski (sic!) krążył ze swoim wojskiem po Indiach, Tracji i Grecji, wszędzie zwalczając tyranię. W końcu trafił do Hiszpanii, by walczyć z Deabosem-Gerionem ${ }^{95}$. Wprowadza w Hiszpanii zwyczaj pochówków oraz bicie monety. Zabijając Geriona, Ozyrys postanawia ocalić jego trzech młodych synów, dając ich na wychowanie Erytrei (imię pokrewne z wyspą i Hesperydą). Gdy tylko dzieci dorastają, wchodzą w spisek z egipskim Tyfonem, który zabija Ozyrysa ćwiartując jego ciało. Dopiero syn Ozyrysa, ów Herkules Libijski (zwany Horusem) wyprawi się do Hiszpanii przeciw trzem Gerionom, by pomścić ojca. W drodze zostawi m.in. Baleusa, jednego z dowódców, który zasiedli Baleary.

W rozdziale XIII, Herkules-Horus, po przybyciu statkami do Kadyksu, stawia dwie skały, nie tyle kolumny, co raczej stosy usypane ze kamieni, mające umocnić brzeg morski ${ }^{96}$. Osiedla w tej okolicy część swych ludzi, Egipcjan, a dokładniej Erytrejczyków, od których weźmie swą nazwę Erythia. Ostatecznie Herkules pokonuje Gerionidów, grzebie ich w Kadyksie i odpływa do Italii z mnóstwem bogactw, między innymi bydła. Jego następcą zostaje nie bezpośrednio Hispan, a Hispalo. Potem, przeżywszy przygody w innych częściach świata, Herkules-Horus powraca, by umrzeć w Hiszpanii i znaleźć spoczynek w Kadyksie. Wersję tę powtórzą później kronikarze Pedro de Medina czy Juan de Mariana.

Wspomniany Ambrosio de Morales był nie tylko kronikarzem Filipa II, ale i ,archeologiem” czy raczej zbieraczem starożytności. Podróżował po Hiszpanii opisując jej relikwie, skarby, zabytki, dokumenty, które zebrał w dziele Las

${ }^{95}$ Morales 1791: 85-91.

${ }^{96}$ Morales 1791: 92. W późniejszej Historia de rebus Hispaniae (1.8-9) autorstwa jezuity Juana de Mariany, Herkules stawia skały, Calpe i Abilę, dopiero po zabiciu Gerionidów. Ów duchowny uznaje Geriona za przybysza z innych stron świata (jego imię ma oznaczać po chaldejsku „obcego, przybysza”), czczonego jako bóg (świątynię na Sycylii zbudowac miał mu... Herkules). Miał on zbudować twierdze w Kadyksie i Gironie, chcąc jako tyran objąć władzę nad całą Hiszpanią. Mariana powtarza zasadniczo kronikę Moralesa. Dodaje, że Ozyrys uczynił Gerionidów wręcz królami Hiszpanii, lecz ci zemścili się, gdyż „pamięć zniewagi trwa dłużej niż wyświadczonej dobroci”: jako duchowny moralnie oceniał postaci. Dodaje, że Herkules Libijski chodził w skórze lwa i z maczugą (choć to chyba ewidentne atrybuty greckiego), bo nie znano wtedy broni żelaznej. Mariana przyznaje, że między autorami nie ma pewności, gdzie został pochowany, wskazując Kadyks lub pobliską Tarifę i dodając wzmiankę o świątyni mu poświęconej. Autor znał źródła antyczne: powołuje się na Diodora, Pliniusza Starszego, Arriana, Plutarcha, Pomponiusza Melę i innych, cf. Mariana 1864: 8-11. 
antigüedades de las ciudades de España (1575). Opisuje w nim Kadyks swoich czasów: morze bardzo zniszczyło wyspę od starożytności, zniknęły ruiny bogatej niegdyś świątyni Herkulesa. Autor wspomina też o ciekawym znalezisku, które świadczy o dawnym znaczeniu wyspy, miedzianych monetach używanych przez dawnych mieszkańców: ,widziałem je i mam nawet jedną. Na jednej stronie monety widać oblicze Herkulesa, młodego bez brody, o krzepkich rysach, z głową okrytą lwią skórą. Po drugiej stronie są dwa tuńczyki, na pamiątkę ich wielkich połowów (...) moneta ta ma napisy, ale są one albo starohiszpańskie, albo raczej punickie, więc nie można ich rozczytać" ${ }^{97}$.

W czasach wspominanych władców Herkules będzie powszechnie występował w ikonografii, podobnie jak w innych krajach Europy ${ }^{98}$. O ile jednak inni monarchowie europejscy będą wykorzystywać figurę Herkulesa czysto alegorycznie, jako wzór cnót moralnych, w Hiszpanii skomplikowane genealogie mitologiczno-biblijne chciały udowodnić osobiste związki genealogiczne tamtejszych monarchów z Herkulesem, czego przykłady widzieliśmy ${ }^{99}$. Również Słupy Heraklesa pojawią się w XVI wieku w hiszpańskiej heraldyce. Pełniąc w średniowieczu symbol granicy świata z hasłem „Non plus ultra” (z księgi Hioba 38.11), zmienią odtąd swe znaczenie. Zamiana hasła ze wstęgi na „Plus ultra" (łac. ,jeszcze dalej”), zachęcać będzie żeglarzy do pokonywania Atlantyku i rozszerzania kolonialnego imperium ${ }^{100}$. Słupy Herkulesa staną się nie granicą, a bramą otwierającą na Nowy Świat. Symbol kolumn przepasanych wstęgą pojawi się również na talarach hiszpańskich (hiszp. real de a ocho, Ryc. 5), oficjalnej walucie okresu imperium hiszpańskiego. Przyjmuje się, że symbol amerykańskiego dolara (\$) przejął tę symbolikę i stanowi uproszczoną wersję wizerunku kolumny przepasanej wstęgą ze wspomnianym mottem. Herkules podbijający Hiszpanię, cywilizujący nowe ziemie, w pełni odpowiada tutaj ideałom konkwisty. Słupy Herkulesa w imperialnych czasach Filipa II jawią się następująco:

Y assi Hercules, aunque con su grande animo acometió passear el universo, alli paro como en verdadero término y cabo del, por dexar a nuestros Españoles la gloria de descubrir tanto del

${ }^{97} \mathrm{Za}$ : Morales 1575: 62.

${ }^{98} \mathrm{Na}$ katafalku pogrzebowym Filipa II zbudowano łuk triumfalny, który przedstawiał Herkulesa trzymającego ziemski glob z napisem „Sufficio solus” (symbol króla utrzymującego świat rozumiany jako królestwo z jego koloniami oraz świat katolicki, którego król jest obrońcą wobec innowierców i reformatorów), cf. Hernández de la Fuente 2012: 80. Wcześniej, w 1570 roku, po stłumieniu rebelii Morysków, Sewilla witała Filipa łukiem triumfalnym z wyobrażeniem Herkulesa z maczugą i jabłkami Hesperyd, cf. Pizarro Gómez 1985: 65-84.

${ }^{99}$ Banach 1984: 61-62. Herkules jako wzór siły moralnej pojawia się już u Seneki, jednak w nowożytności spojrzenie takie odnawiają kataloński Enric de Villena Els dotze treballs d'Hèrcules (1417) oraz Coluccio Saluti w pracy De laboribus Herculis z 1406 (Hernández de la Fuente 2012: 77-78). Do rozpowszechnienia mitu „chrześcijańskiego Herkulesa” na rozstajnych drogach przyczyni się także Erazm z Rotterdamu (Banach 1984: 70-73).

${ }^{100}$ Checa Cremades 1999: 404. 
mundo como faltaba, y que las venturosas armas de nuestros Reyes extendiesen el nombre de Jesucristo y su fe Católica con sus reinos y señoríos por tierras y gentes tan estrañas y tan apartadas como son las a donde navegamos: y que las columnas de nuestro gloriosísimo emperador Carlos Quinto con el Plus Ultra sin término, se pusiesen en otro estrecho que mostrase claramente como para su ánimo y el de sus españoles, ningun fin ni paradero tenía el mundo ${ }^{101}$.

I tak, Herkules, choć w swej odwadze zdołał przebyć cały świat, tam właśnie się zatrzymał, na jego prawdziwym krańcu, aby zostawić naszym Hiszpanom chwałę odkrycia na świecie tego, co brakowało: by pomyślne wojska naszych Królów rozciągnęły imię Jezusa Chrystusa i ich katolicką wiarę, ze swymi królestwami i władztwami, na ziemie i ludy tak obce i odległe, jak te do których żeglujemy: i aby kolumny naszego chwalebnego Imperatora Karola V, wraz z bezgranicznym „PLUS ULTRA”, postawić w innej cieśninie, by jasno pokazać, że dla jego odwagi i jego Hiszpanów, świat nie miał żadnego kresu, ani miejsca postoju.

(przeł. D.B.)

Zauważmy, że nowym Herkulesem stawiającym słupy jest tutaj cesarz Karol V, a celem przyświecającym wyprawie - szerzenie chrześcijaństwa w Nowym Świecie. Warto dodać, że Kadyks, zwłaszcza w czasach późnonowożytnych stał się ważnym portem handlującym z Ameryką. Koloniści nadali miano Cádiz kilku miejscowościom na drugiej półkuli. Dziś nazywają się tak miasta i miasteczka na Filipinach i w Stanach Zjednoczonych.

Powszechna obecność Herkulesa w ludowej tradycji iberyjskiej sprawiła, że przypisano mu budowę wielu miast i monumentów: mostów, wież, łuków triumfalnych. Słowem, wszystko, czego pochodzenia lud nie był pewien, przypisywano Herkulesowi. Jednak w epoce nowożytnej dają się słyszeć głosy krytyki tego zjawiska, także wśród kronikarzy. Autorzy Crónica General odnoszą się krytycznie do nazywania Calpe (tj. Skały Gibraltarskiej) „słupem” czy „kolumną”, podkreślając, że jest ona dziełem natury. To ludzka wyobraźnia i poetycka fikcja sprawiły, że ludzie

les llamaron coluna, pues (...) pareció una cosa hecha de manos: y luego fingieron haberlo hecho no sé qual de sus Hércules,

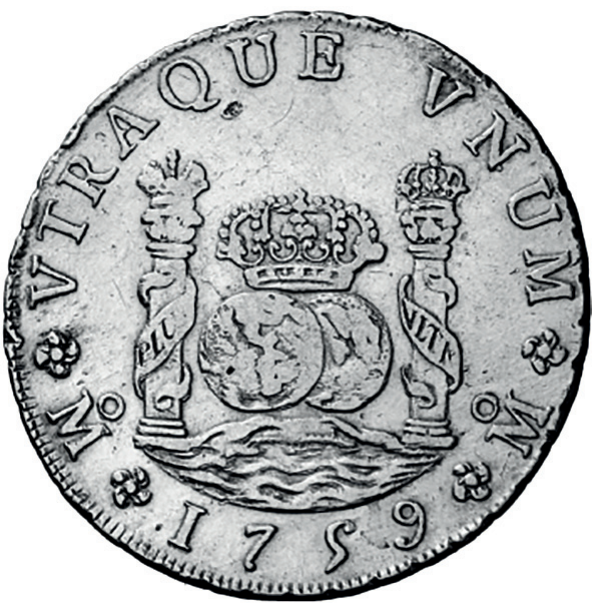

Ryc. 5. Real de a ocho z widocznymi Słupami Herkulesa i wstęgami PLUS ULTRA, późniejszy symbol dolara. Meksyk, 1759. Źródło:[https://es.wikipedia. org/wiki/Real_de_a_8\#/media/File:Ocho_ reales_de_plata_1759_(reverso).jpg] (dostęp 13.03.2018)

${ }^{101}$ Morales 1575: 49, pisownia oryginalna. 
seyendo verdaderamente comun obra de naturaleza, digna cierto de ser considerada, si miramos el asiento, faccion, y figura que Dios nuestro Señor en ella puso: cuya labor es como lo son todas las cosas criadas de su calidad y manera ${ }^{102}$.

nazwali je kolumną, bo (...) wydała im się to rzecz uczyniona ludzką ręką: a później wymyślili, że uczynił to któryś z ich Herkulesów, choć było to w istocie dzieło natury, oczywiście godne podziwu, patrząc na położenie, strukturę i kształt, jakie nałożył na nie Bóg, nasz Pan: którego dzieło jest jak wszystkie rzeczy powstałe za Jego sprawą i doskonałością.

(przeł. D.B.)

Z kolei szesnastowieczny kleryk i erudyta portugalski, Gaspar Barreiros, krytykował błędne mniemania kronikarzy i ludu wobec budowli przypisywanych Herkulesowi. Wspomina, że nazwę miasta Mérida (pochodzącą w istocie od emerytowanych generałów rzymskich, stąd Emerita Augusta) uznawano za zniekształcenie od „memorida”, czyli „upamiętnienia” walki Herkulesa z Gerionem. Barreiros, rozpoznając budownictwo rzymskie, podważa i bez ogródek krytykuje dawnych kronikarzy, którzy nader łatwo wciągali Herkulesa do iberyjskiej historii i architektury:

Sta Merida asentada en lugar campestre ao longo da ribeira de Guadiana a qual passam por huna fermosa \& comprida ponte feita de miu grossas pedras de cantaria, na architectura la qual se conhece bem ser obra de Romanos, posto que O-Rasis diga ser obras de Hercules porque ja tenho dicto que foi idiota e de pouco conhecimento de historias $\&$ cosas antigas (...) E destas vaidades não há lugar nobre em Espanha, que não tenha suas relíquias, ou em torres, ou em pontes, ou em quaisquer outros edifícios, como ora nestes de Merida, que a gente ignorante usurpa como por mostra \& argumento de sua nobreza \& antiguidade. Digo tudo isto porque nos mais dos lugares nobres de Hespanha me aconteceu achar sempre qualquer coisa desta qualidade que o povo afirma com muita contumancia ser de Hércules, tão grande fortuna foi deste homem, que com uns poucos trabalhos \& os mais deles fabulosos, roubou a fama de tantos alheios ${ }^{103}$.

Ta Merida leży wśród pól wzdłuż koryta rzeki Gwadiany, przez którą przechodzi się przez piękny i długi most z grubych kamieni, a w jego architekturze można rozpoznać dobrze dzieło Rzymian. Skoro Al-Rasi mówił, że to dzieło Herkulesa, to dlatego, że był idiotą, jak już powiedziałem, i mało znał się na historii i starożytnościach (...) Nie ma w Hiszpanii żadnego szlachetnego miejsca, które nie miałoby pozostałości po nim: czy to w wieżach czy mostach czy w jakichkolwiek innych budynkach, jak tu w Meridzie, gdzie nieświadomy lud pokazywaniem i opowiadaniem przypisuje sobie dawność i szlachetność. Mówię o tym wszystkim, bo w każdym ze szlachetniejszych miejsc Hiszpanii spotykałem się z tego rodzaju obiektami, o których lud poświadcza z dumą, że należą do Herkulesa. Tak wielkie było szczęście tego człowieka, że z pomocą niewielu prac i to w dodatku zmyślonych, ukradł sławę tylu innym. (przeł. D.B.)

${ }^{102}$ Morales 1791: 92-93, rozdział XIII; pisownia oryginalna.

103 Barreiros 1561: 17; 21-22, [http://purl.pt/14298/4/323982_PDF/323982_PDF_24C-R0150/323982_0000_Obra\%20Completa_t24-C-R0150.pdf], dostęp 02.03.2018, pisownia oryginalna. 
Nie powinna nas dziwić reakcja Portugalczyka, skoro Herkulesowi przypisywano nie tylko budowę mostów czy wież, ale nawet założenie uniwersytetu w Salamance! ${ }^{104}$. Jednak postać Herkulesa w historiografii, literaturze i sztuce trwać miała jeszcze długo, a przejawy krytyki nie zdołały wykorzenić obecności Herkulesa także ze współczesnej nam kultury krajów hiszpańskojęzycznych.

Słupy Heraklesa widoczne są $\mathrm{w}$ architekturze niektórych hiszpańskich i amerykańskich budynków i bram (np. w bramie portu w Kadyksie). Widnieją w herbie i fladze Hiszpanii, herbie niektórych miast (Kadyksu, pobliskiego San Fernando, leżącej w północnej Afryce Melilli, meksykańskich Veracruz i Tabasco, kalifornijskiego San Diego, peruwiańskiego Trujillo) i regionów (Andaluzji i Extremadury). Ponadto w miejscu domniemanych Kolumn, po obydwu stronach Cieśniny Gibraltarskiej, znajdują się dziś pomniki. O południową kolumnę rywalizują znajdujące się w Maroku wzgórza Dżabal Musa oraz Monte Hacho. W hiszpańskim mieście Ceuta stoi posąg Herkulesa: nagi mocarz siłuje się między dwiema kolumnami, rozpychając je na boki. Pomnik na szczycie Skały Gibraltarskiej przedstawia dwie kolumny opasane wstęgą „Mons Calpe” i „Mons Abila” oraz wpisaną w nie tarczę z mapą Starego Świata z jednej strony i Nowego Świata z drugiej. W prowincji Kadyks zbudowano z kolei dwa bliźniacze nowoczesne wieżowce zwane „Torres de Hércules” należące do Polígono Industrial Las Marismas, ukończone w 2009 jako najwyższe wówczas budynki w Andaluzji.

Jak wykazały przytoczone źródła i ich analiza, wyobrażenia o wyprawie Heraklesa na krańce świata, o jego walce z Gerionem oraz słupach, ulegały wielu zmianom, uzależnionym często od okoliczności powstania tekstu, przy czym w przypadku kronik iberyjskich był to kontekst wysoce polityczny. Wersje Hezjoda czy Stezychora to jeszcze w pełni mity o wielkim herosie wykonującym jedną ze swych prac. Wersja Diodora Sycylijskiego oraz podobne do niej wersje ze średniowiecznych i nowożytnych kronik przedstawiają nam innego bohatera. Patronuje on czasom rekonkwisty i późniejszego zjednoczenia, stając się (on lub jego synowie, w zależności od wersji) wodzem i królem, osobą niosącą nową cywilizację, wzorem cnót monarszych. W czasach hiszpańskiego imperium Herkules i jego Słupy, dotąd postrzegane jako symboliczny koniec znanego świata, zaczynają przyświecać ideom kolonializmu zamorskiego i jedności chrześcijańskiego świata. Zupełnie odrębnym wątkiem (choć również uwikłanym w mity i historie kronikarskie), jest kwestia Heraklesa fenickiego (Melkarta). Jego kult w fenickim Gadir, udowodniony przez archeologów i historyków, komentowany był, jak widzieliśmy, w świecie grecko-rzymskim. Utożsamienie Herkulesa z Melkartem doprowadziło do kontrowersji wynikającej z odmiennego wieku obydwu bóstw. Chcąc rozwiązać tę rozbieżność, jeszcze starożytni autorzy wyróżnili kilku Herkulesów, czego echa (uwikłane oczywiście w specyfikę kronik

${ }^{104}$ Hernández de la Fuente 2012: 80. 
i ich propagandowy charakter) znaleźć możemy u iberyjskich historiografów. Kronikarze ci nie tylko podjęli wątek kilku Herkulesów, ale zaadaptowali go do politycznych celów.

\section{BIBLIOGRAFIA}

Źródła, przekłady, komentarze:

Aeliani De natura animalium. Varia historia, epistolae et fragmenta; Porphyri Philosophi De abstinentia et De antro nympharum; Philonis Byzantii De septem orbis spectaculis, recognovit adnotatione critica et indicibus instruxit R. Hercher, Parisiis 1858.

Alfonso X Rey de Castilla, Primera Crónica General o sea Estoria de España que mandó componer Alfonso el Sabio y se continuaba bajo Sancho IV en 1289, vol. I, ed. Ramón Menéndez Pidal, Madrid 1906, [https://bibliotecadigital.jcyl.es/es/consulta/registro.cmd?id=16550], dostęp 2.03.2018.

D. Alighieri, Boska komedia, przeł. E. Porębowicz, Warszawa 1978.

L. Ampelius, Liber memorialis, [http://www.thelatinlibrary.com/ampelius.shtml], dostęp 2.12.2018.

Apollodorus Atheniensis, The Library: in two volumes, vol. I, przeł. J.G. Frazer, London 1921.

Alfonso El Sabio, Primera Crónica General de España que mandó componer Alfonso el Sabio y se continuaba bajo Sancho IV en 1289, ed. R. Menéndez Pidal, Madrid 1955.

Arrian, The Anabasis of Alexander; or, The history of the wars and conquests of Alexander the Great, transl. E.J. Chinnock, London 1884.

G. Barreiros, Chorographia de alguns lugares que stam em hum caminho que fez Gaspar Barreiros no anno de MDXXXXVJ começando na cidade de Badajoz em Castella até à de Milam em Italia; com algumas outras obras cujo catalogo vai scripto com os nomes dos dictos lugares na folha seguinte, Coimbra 1561, [http://purl.pt/14298/4/323982_PDF/323982_PDF_24C-R0150/3239820000_Obra\%20Completa t24-C-R0150.pdf], dostęp 2.03.2018.

Cicero, De natura deorum, [http://www.thelatinlibrary.com/cicero/nd3.shtml], dostęp 2.03.2018.

Crónica del moro Rasis, versión del Ajbar Muluk al-Andalus de Ahmad ibn Muhammad ibn Musa Al-Razi, ed. D. Catalán, M.S. de Andrés, Madrid 1975, 889-955.

G. Díaz de Games, El Victorial, crónica de don Pero Niño, Conde de Buelna, ed. J. Mata de Carriazo, Madrid 1940.

Diodor Siculus, Library of History, vol. II, transl. C.H. Oldfather, Loeb Classical Library, Harvard 1935.

A. Durán, Romancero General, vol. X, Madrid 1849.

Eurypides, Ifigenia w kraju Taurów, w: Tragedie, vol. II, przeł. J. Łanowski, Warszawa 2006.

Herodot, Dzieje, przeł. S. Hammer, Warszawa 2005.

Hezjod, Teogonia, przeł. J. Łanowski, Warszawa 1999, [http://katedra.uksw.edu.pl/biblioteka/hezjod teogoinia.pdf], dostęp 15.09.2016.

Hygini Fabulae, recens. prolegomenis, commentario, appendice instruxit H.I. Rose, Lugduni Batavorum 1967.

Liber Sancti Jacobi. Codex Calixtinus, transl. A. Moralejo, C. Torres, J. Feo, Santiago 1951, 415416.

Lucius Ampelius, Liber memorialis, [http://www.thelatinlibrary.com/ampelius.shtml].

Isidore of Seville, Etymologiarum sive originum libri XX, [http://www.thelatinlibrary.com/isidore. html], dostęp 2.03.2018.

R. Jiménez de Rada, Historia de los hechos de España, transl. J. de Fernández Valverde, Madrid 1989.

T. Liwiusz, Dzieje Rzymu od założenia miasta, Księgi XXI-XXVII, przeł. M. Brożek, WrocławWarszawa-Kraków 1974. 
Owidiusz, Fasti. Kalendarz poetycki, przeł. E. Wesołowska, Wrocław-Warszawa-Kraków 2008. Owidiusz, Metamorfozy, przeł. A. Kamieńska, S. Stabryła, Wrocław-Warszawa-Kraków 1995.

J. de Mariana, Obras del padre Juan de Mariana, vol. I, Madrid 1864.

Pauzaniasz, Wędrówka po Helladzie. Na olimpijskiej bieżni $i$ w boju, przeł. J. Niemirska-Pliszczyńska, Wrocław 2004.

Pliniusz St., K. Pliniusza Starszego Historyi Naturalnej Ksiag XXXVII, przeł. J. Łukaszewicz, Poznań 1845.

Poetarum Melicorum Graecorum Fragmenta, ed. M. Davies, Oxford 1991.

Pomponiusz Mela, Chorografia czyli Opis kręgu ziemi, przeł. M. Golias, red. S. Szarypkin, K.T. Witczak, Piotrków Trybunalski 2011.

J. Mariana, Obras del padre Juan de Mariana, Madrid 1864.

F. de Ocampo, Los cuatro libros primeros de la crónica general de España que recopila el maestro Florián de Ocampo, criado y cronista del emperador rey nuestro señor por mandado de su magestad cesárea, Zamora 1543.

F. de Ocampo, Las cuatro partes enteras de la Crónica de España que mandó componer el

Sereníssimo rey don Alonso llamado el Sabio: donde se contienen los acontescimientos y hazañas mayores y mas señaladas que suçedieron en España desde su primera poblaçion hasta casi los tiempos del dicho señor rey, Zamora 1541.

A. de Morales 1575, Antigüedades de las ciudades de España, Alcalá de Henares 1575.

A. de Morales, Coronica General de España que continuaba Ambrosio de Morales, coronista del Rey Nuestro Señor Don Felipe II, vol. I, Madrid 1791.

Platon, Kritias; Timajos, w: Dialogi, vol. II, przeł. W. Witwicki, Kęty 1999.

Poetarum Melicorum Graecorum Fragmenta, ed. M. Davies, Oxford 1991.

L.A. Seneca, Hercules furens; Trojanerinnen = Troades; Medea; Phaedra; Octavia $=$ Octavia praetexta incerti poetae, übers. und erl. von Theodor Thomann, Zürich-München 1978.

M. Servius Honoratus, Commentary on the Aeneid of Vergil, ed. Georgius Thilo, [http:// www.perseus.tufts.edu/hopper/text?doc $=$ Serv. + A. $+8.300 \&$ fromdoc $=$ Perseus $\% 3$ Atext\%3A1999.02.0053], dostęp 2.12.2018.

Strabo, The Geography, Loeb Classical Library, transl. H.L. Jones, Harvard 1917-1932.

Swetoniusz, Boski Juliusz, w: Żywoty Cezarów, vol. I, przeł. J. Niemirska-Pliszczyńska, Wrocław 2004.

Wergiliusz, Eneida, przeł. K. Karyłowski, Wrocław-Warszawa-Kraków 1981.

Opracowania:

Agra Bernadal 2018: J. Agra Bernadal, Sobre el controvertido origen de A Coruña, w:

[https://www.elcorreogallego.es/tendencias/el-correo2/ecg/controvertido-origen-coruna/idEdicion-2018-07-15/idNoticia-1126926/], dostęp 30.09.2018.

Banach 1984: J. Banach, Hercules Polonus. Studium z ikonografii sztuki nowożytnej, Warszawa 1984.

Bejarano 1987: V. Bejarano, Hispania Antigua según Pomponio Mela, Plinio el Viejo y Claudio Ptolomeo, Barcelona 1987.

Blázquez Martínez 1983: J.M. Blázquez Martínez, Gerión y otros mitos griegos en Occidente, „Gerión. Revista de Historia Antigua” 1 (1983), 21-38.

Boczkowska 1993: A. Boczkowska, Herkules i Dawid z rodu Jagiellonów, Warszawa 1993.

Bravo Jiménez 2014: S. Bravo Jiménez, Aspectos mitológicos de Baelo y Mellaria y su relación con el estrecho de Gibraltar, „AL QANTIR”, 16 (2014), 96-101.

Caballero López 2002: J. Caballero López, Mito e historia en la Crónica General de España de Florián de Ocampo, „AISO” 6 (2002).

Cagan 2010: R.L. Cagan, Los Cronistas y la Corona, Madrid 2010.

Camacho 2016: P. Fernandez Camacho, La ciudad bipolar. La construcción de la imagen de Cádiz 
en la historiografía del siglo XVI a través de las fuentes clásicas, „Ágora. Estudos Clássicos em debate", 18 (2016).

Checa Cremades 1999: F. Checa Cremades, Carlos V. La imagen del poder en el Renacimiento, Madrid 1999.

Córdoba 1985: P. Córdoba, Las Leyendas en la histografía del Siglo de Oro: el caso de los ,falsos cronicones”, „CRITICON” 30 (1985), [https://cvc.cervantes.es/literatura/criticon/ PDF/030/030_239.pdf], dsotęp 2.03.2018.

Caballero 2002: J.A. Caballero, Annio de Viterbo y la historiografía española del XVI, w: Nieto Ibáñez, León 2002.

Corzo Sánchez 2005: J.R. Corzo Sánchez, Sobre las primeras imágenes y la personalidad originaria de Hercules Gaditanus, „SPAL” 14 (2005), 91-122.

Danielewicz 1984: J. Danielewicz, Wstęp, w: Liryka starożytnej Grecji, Wrocław-Warszawa-Kraków-Gdańsk-Lódź 1984.

Domínguez Arjona 2000: J. Domínguez Arjona, La Puerta de Jerez. Poética Historia de Sevilla, w: La Sevilla que no vemos, [http://www.galeon.com/juliodominguez/puertajerez.htm], dostep 15.10.2016.

Fernandez de Valverde 1989: J. Fernandez de Valverde, Introducción w: R. Jiménez de Rada, Historia de los hechos de España, Madrid 1989.

Fierro Cubiella 1995: J.A. Fierro Cubiella, Gadir: la historia de un mito, Cádiz 1995.

González García 1997: F.J. González García, Hércules contra Gerión. Mitos y leyendas de la Torre de Hércules, vol. II, Oleiros (A Coruña), 1997-1998.

González Wagner 2014: C. González Wagner, Tartessos. Mito e historia, Madrid 2014.

Govers 2009: R. Govers, Choking the Mediterranean to dehydration: The Messinian salinity crisis, „Geology”, February 2009; vol. XXXVII; no. 2, 167-170, [http://www.geo.uu.nl/ wwwtekto/publications/Govers_Geology09.pdf], dostęp 2.03.2018.

Graves 1974: R. Graves, Mity greckie, przeł. H. Krzeczkowski, Warszawa 1974.

Grieve 2009: P.E. Grieve, The Eve of Spain. Myths of Origins in the History of Christian, Muslim, and Jewish Conflict, Baltimore 2009.

Hernández de la Fuente 2012: D. Hernández de la Fuente, Herkules w Hiszpanii: szkic o mitologii i symbolizmie, w: Prace Herkulesa - człowiek wobec wyzwań, prób i przeciwności, M. CieślaKorytowska, O. Płaszczewska (red.), Kraków 2012.

Lazzeri 2008: M. Lazzeri, Studi sulla Gerioneide di Stesicoro, „Quaderni del Dipartimento di Scienze dell' Antichità" 35 (2008).

Lomas Salmonte 2005: F.J. Lomas Salmonte, Historia de Cádiz, Madrid 2005.

Morford, Lenardon 1991: M. Morford, R. Lenardon, Classical Mythology, London 1991.

Ortega Feliu, Aladro Prieto 2012: P. Ortega Feliu, J.M. Aladro Prieto, Guía de las Fortificaciones y Sistemas de Defensa de la Bahía de Cádiz, Cadiz 2012.

Pietrzak-Thébault 2012: J. Pietrzak-Thébault, Herkules na rozdrożu - między ideałem rycerza a 'męża szlachetnego' $i$ monarchy nowych czasów, w: Prace Herkulesa - człowiek wobec wyzwań, prób i przeciwności, M. Cieśla-Korytowska, O. Płaszczewska (red.), Kraków 2012.

Pizarro Gómez 1985: F.J. Pizarro Gómez, Antigüedad y emblemática en la entrada triunfal de Felipe II en Sevilla en 1570, „NORBA-ARTE” 6 (1985), 65-84.

Plácido 1990: D. Plácido, Le vie di Ercole nell'estremo Occidente, w: Ercole in Occidente, A. Mastronique (red.), Trento 1990, 63-80.

Radziszewski 2005: H. Radziszewski, Mityczne początki Kadyksu: wybór źródet, „Studia i materiały archeologiczne" 12 (2005), 163-168.

Rico 1984: F. Rico, Alfonso el Sabio y la General Estoria, Barcelona 1984.

Sanctis 2011: D. De Sanctis, „Quando Eracle giunse a Erythia”. Gerione in Esiodo, Stesicoro ed Acateo, „SCO” 57 (2011), 57-72, [https://datospdf.com/download/quando-eracle-giunsea-erythia-gerione-in-esiodo-stesicoro-ed-ecateo-_5a4c0ef1b7d 7bcb74fded61d_pdf], dostęp 1.03.2018. 
Szarypkin 2011: S. Szarypkin, Wstęp w: Pomponiusza Meli Chorographia czyli opis okregu ziemi, Piotrków Trybunalski 2011.

Oria Segura 1996: M. Segura, Hércules en Hispania: una aproximación, Barcelona, 1996.

Szoka 2010: A.I. Szoka, Herkules konkurent Chrystusa: studium na tle zmagań religii pogańskiej z chrześcijaństwem w późnym antyku (do końca IV w.), Kraków 2010.

Tate 1970: R.B. Tate, Ensayos sobre la historiografía peninsular del siglo XV, trad. J. Díaz, Madrid 1970.

Torres Ortiz 2002: M. Torres Ortiz, Tartessos, Madrid 2002.

Tregelles 1949: S.P. Tregelles, Gesenius'Hebrew-Chaldee lexicon, Grand Rapids 1949.

Tyloch 1988: W. Tyloch, Religie Fenicji i Syrii, w: Zarys dziejów religii, J. Keller (red.), Warszawa 1988.

Vella 1986: H.C.R. Vella, Juno and the Fertility at the Sanctuary of Tas-Silg, Malta, „Archaeology and Fertility Cult in Ancient Mediterranean", A. Bonanno (ed.), Amsterdam 1986.

Vigo Trasancos 2010: A. Vigo Trasancos, Tras las huellas de Hércules. La torre de Crunna y el Pórtico de la Gloria, „QUINTANA” 9 (2010), 217-233.

Watkins 1995: C. Watkins, How to Kill a Dragon, Oxford 1995.

West 2007: M.L. West, Indo-European Poetry and Myth, Oxford 2007.

\section{HÉRCULES Y GERIÓN, REYES DE ESPAÑA. EL MITO Y SU RECEPCIÓN EN CRÓNICAS IBÉRICAS MEDIEVALES Y MODERNAS}

\section{Resumen}

El artículo presenta la adopción de los mitos antiguos sobre Hércules y Gerión en una selección de crónicas españolas y su evolución en las mismas, en concreto las elaboradas por Al-Razi, El Toledano, Alfonso X, Ambrosio de Morales, Florián de Ocampo y Juan de Mariana. La primera parte se centra en el análisis de textos antiguos, griegos y romanos (desde Hesíodo hasta Plinio el Viejo). Podemos observar cómo Hércules pasa de ser un héroe griego que lleva el ganado de Gerión (en Hesíodo y el Pseudo-Apollodoro) a convertirse en rey y caudillo (en Diodoro Siculo). Se examina también la cuestión del santuario de Hércules-Melkart en Gadir, así como la distinción por parte de los antiguos entre varios Hércules y su proveniencia (de Grecia, de Egipto o de Tiro). Tratamos igualmente el tema de las diferentes interpretaciones acerca de las Columnas de Hércules y su localización. En la segunda parte se analiza de qué modo presentaban a Hércules los cronistas en sus obras y cuál era su objetivo artístico y político. Su imagen fue utilizada por los cronistas como símbolo de la reconquista y la aspiración a una España medieval más unida (Alfonso X), además de la fundación de las primeras dinastías reales. En el Siglo de Oro cambia también el significado de las columnas: dejan de marcar el fin del mundo conocido y empiezan a expresar la conquista de América y la difusión de la fe cristiana (en Morales, Ocampo y Mariana). 